\title{
Predatory mite instars (Acari, Mesostigmata) and decomposing tree leaves in mixed and monoculture stands growing on a spoil heap and surrounding forests
}

\author{
Cezary K. Urbanowski ${ }^{1}$ (D) . Paweł Horodecki ${ }^{2}$ (D . Jacek Kamczyc ${ }^{1}$ (D) . \\ Maciej Skorupski ${ }^{1}$ (D) Andrzej M. Jagodziński ${ }^{1,2}$ (D)
}

Received: 3 February 2021 / Accepted: 20 July 2021 / Published online: 26 July 2021

(C) The Author(s) 2021

\begin{abstract}
In the past, ecological research mainly omitted the sexual and developmental variability of mite communities, and therefore could not fully reflect the actual state and function of mite communities in the ecosystems studied. The aim here was to analyze how habitat conditions (mixed vs. monoculture stands) and single-species litter of 14 tree species (in mixed stands) affect the sex and developmental stages of Mesostigmata mites living on the decomposing litter. The research was conducted in 2011-2016, at the Bełchatów Lignite Mine external spoil heap (Central Poland) in mixed stands growing on the spoil heap, as well as in pine and birch monoculture stands growing on the spoil heap and an adjacent forest area. We found significant influences of habitat on females, males and juveniles. Additionally, we found that soil mean temperature had a significant effect on males and juveniles, but not on females. Moreover, despite the insignificant influence of litter species on mite communities, we found that percentage litter mass loss significantly affected female and juvenile mites. Taking into account habitat type, the percentage litter mass loss significantly affected female and male mites, but not juveniles. The mite abundance calculated per dry litter mass usually gradually increased during decomposition. Interestingly, the highest mean female, male and juvenile abundances were recorded in birch stands growing on the adjacent forest area; however, juvenile mites were also very numerous in mixed stands on spoil heap. Therefore, our results confirm that mixed stands on post-mining areas are a potentially better habitat for development of mesostigmatid communities compared to monocultures, among others by relatively higher humidity and lower temperatures.
\end{abstract}

Keywords Post-mining site - Afforestation - Soil reclamation - Organic matter · Developmental stages $\cdot$ Mite assemblages

Cezary K. Urbanowski cezar.u93@gmail.com

1 Department of Game Management and Forest Protection, Poznań University of Life Sciences, Wojska Polskiego 71C, 60-625 Poznań, Poland

2 Institute of Dendrology, Polish Academy of Sciences, Parkowa 5, 62-035 Kórnik, Poland 


\section{Introduction}

The decomposition process, the physicochemical breakdown of organic plant matter, is one of the most important processes occurring in nature (Field et al. 1998; Schulze 2000; Graca et al. 2005; Berg and McClaugherty 2014; Eisenhauer et al. 2017; Fujii and Takeda 2017). Decomposition is regulated by many natural factors, including habitat conditions (Horodecki and Jagodziński 2019) and soil organisms (Urbanowski et al. 2018, 2021; Horodecki et al. 2019), and it still requires more scientific attention on habitats transformed by anthropogenic activity (Berg and McClaugherty 2014; Eisenhauer et al. 2017; Horodecki et al. 2019).

Soil fauna can be directly related to the decomposition of litter organic matter (Fujii and Takeda 2017); however, soil predators that feed on soil organisms can be indirectly involved in the decomposition of litter (Vreeken-Buijs and Brussaard 1996; Lawrence and Wise 2000, 2004; Urbanowski et al. 2018, 2021). One of the most numerous microarthropod groups living in the topsoil is mesostigmatid mites (Koehler 1997, 1999). The majority of mesostigmatid mites are predators that mainly feed on many groups of soil animals (Koehler 1999; Wissuwa et al. 2012; Skorupski et al. 2013). Their community structure, due to high abundance, high susceptibility to environmental factors and occupation of higher trophic levels, makes them valuable bioindicators (Madej 2004; Beaulieu and Weeks 2007; Skorupski et al. 2013).

Previous studies focused on species richness and community structure; however, this topic omitted the changes of population structure (sex ratio and instar proportion), and therefore could not fully reflect the actual population state as well as its function in the ecosystems studied. Changes of population structure may strongly affect the ecosystem functions performed by species forming a community and significantly change the processes taking place in a given ecosystem (Rudolf and Rasmussen 2013). These changes are also noticeable among communities of edaphic fauna, including soil mites. Properly preserved structure of soil mite communities, especially predators, is important for ecosystem balance, as it determines the continuity of these communities over time (Walter and Proctor 2013; FAO 2020). The mite assemblages are influenced by many external factors, not only natural, but also anthropogenic (Madej 2002; Skubała 2002b; Rudolf and Rasmussen 2013). Soil mite communities are also affected by external interactions with other species and soil organisms (Walter and Proctor 2013; Frouz 2018). Such relationships are willingly studied and relatively well-known (Mwabvu 2014; Mueller et al. 2016; Brückner et al. 2017; Seniczak et al. 2018; Frouz 2018), while less attention has been given to intrapopulation relationships and community structure (Rudolf and Rasmussen 2013), including developmental stages of mites (Seniczak et al. 2014, 2018; Salmane and Spungíis 2015; Urbanowski et al. 2018, 2021). A better understanding of the sex and developmental structure of soil mite communities could contribute to a better understanding of soil biodiversity and ecological functions of soil mites. This topic seems even more important in the context of soil revitalization on areas transformed by human activity.

The developmental instars of mesostigmatid mites include adult (males, females) and three juvenile instars (deutonymphs, protonymphs and larvae) (Giljarov and Bregetova 1977; Gwiazdowicz 2007). The life strategy of gamasid mites depends on their developmental stage due to differences in the optimal living conditions and adaptability to the environment (Huhta and Hänninen 2001). Sclerotization and body structure affect water loss from the mite body, as well as their susceptibility to insolation and fluctuations of environmental factors (Madej 2002; Skubała 2002b). Thus, more sclerotized and larger 
adult developmental stages should be more resistant to water loss, which makes them less susceptible to changes of climatic temperature and humidity compared to juvenile mites. Therefore, we may expect differences in proportional abundance of adults and juvenile instars in various habitats, including decomposed litter.

Some studies focused also on sex ratio and life strategy of Mesostigmata, including parthenogenesis (Norton et al. 1993; Błoszyk et al. 2004). Mites, including Mesostigmata, are highly diverse in terms of the reproduction types (Bogdanowicz et al. 2008). For example, Błoszyk et al. (2004) stated that many mesostigmatid mite taxa are parthenogenetic species. Moreover, they revealed that mesostigmatid mite taxa which reproduced without males were associated with forest litter and soil, whereas bisexual species with relatively unstable microenvironments. Also, Norton et al. (1993) provides a great outline of different reproduction types for soil Mesostigmata, which affect mesostigmatid sex ratio.

Recognition of the details of mite development should be used not only to understand the biology and ecology of economically important mesostigmatid species (Azevedo et al. 2018; Roth et al. 2020; Oliveira et al. 2020), but also to create a better bioindication tool based on ecology and biology of individual mesostigmatid species (Urbanowski et al. $2018,2021)$. Therefore, the aim of our research was to analyze how different habitat conditions (habitat type experiment; mixed stands vs. monoculture stands) and single litter types (single litter species; litter type experiment conducted in mixed stands) affects the developmental stages (females, males and juvenile instars) of Mesostigmata mite communities living in the decomposing litter in monoculture stands of silver birch (SHbirch) and Scots pine (SHpine), and mixed stands (SHmixed) on an external post-mining spoil heap, as well as in adjacent monoculture stands of silver birch (FHbirch) and Scots pine (FHpine) on forest land.

The availability of micro- and macro-elements contained in the soil is often very limited for soil organisms (Chaturvedi and Singh 2017; Sako et al. 2018). The microhabitat conditions of the topsoil significantly shape the soil fauna communities through the availability of nutrients (Frouz 2018; Urbanowski et al. 2021). In addition, many studies show that a higher diversity of the stand species composition (mixed stands) increases resistance to extreme climatic factors (Neuner et al. 2015; Vitali et al. 2018; Vacek et al. 2021); moreover, it also has a positive effect on soil fauna when compared with single-species stands (Cavard et al. 2011; Korboulewsky et al. 2016; Urbanowski et al. 2021). Therefore, we hypothesized that (1) habitat conditions (mixed stands vs. monoculture stands; spoil heap vs. forest land) would significantly affect the abundance of each gamasid mite developmental stage. We subsequently hypothesized that abundance of females, males and juvenile instars would be (1A) lower in monoculture stands compared to mixed stands, and (1B) lower on the spoil heap compared to adjacent forest area.

As many studies revealed, mesostigmatid mites feed primarily on herbivorous, fungivorous and saprophagous organisms (Koehler 1999; Wissuwa et al. 2012; Skorupski et al. 2013), which may be directly dependent on fallen litter features (Fujii and Takeda 2017; Kamczyc et al. 2019; Urbanowski et al. 2021). Moreover, microhabitat properties (Frouz 2018), including leaf structure (Schmidt 2014), as well as soil-forming processes, including forest litter decomposition (Osler et al. 2004; Urbanowski et al. 2018, 2021), may significantly shape soil fauna communities, including mesostigmatid mites. Therefore, we hypothesized that (2) the litter species would significantly affect the abundance of each mesostigmatid developmental stage. Finally, we hypothesized that (3) as litter decomposition progressed with collection date, the abundance of females, males and juveniles would differ significantly among collection dates. 


\section{Material and methods}

\section{Site description and experimental design}

The research was established in 2011-2016 at the external spoil heap (Bełchatów Lignite Mine, Mount Kamieńsk, Central Poland; 51 $\left.12^{\prime} 54^{\prime \prime} \mathrm{N}, 1^{\circ} 26^{\prime} 04^{\prime \prime} \mathrm{E}\right)$. The spoil heap was formed to a relative height of approx. $190 \mathrm{~m}$ above the level of the surrounding forest land in the years 1977-1993 (Pietrzykowski 2010; Rawlik et al. 2018a). The total area of the spoil heap is 1471 ha and today it is the largest facility of its type in Central and Eastern Europe (Jagodziński et al. 2018). The most common soils on the spoil heap toplayer are Quaternary loamy, gravelly sands with sporadic occurrences of loams and clays. Additionally, the soil contains tertiary sands with high acidity $(\mathrm{pH}<4.5)$ with loam and clay inclusions (Pietrzykowski and Daniels 2014). The soil substrate is very poor in organic matter, additionally there is a toxic tertiary substrate on the top in some places (Jagodziński et al. 2018).

Weather conditions were described on the basis of the nearest meteorological station $\left(51^{\circ} 43^{\prime} 19^{\prime \prime} \mathrm{N}, 19^{\circ} 23^{\prime} 53^{\prime \prime} \mathrm{E}, 179 \mathrm{~m}\right.$ a.s.l.). The average precipitation and temperature in the study area were $665 \mathrm{~mm}$ and $8.65^{\circ} \mathrm{C}$, respectively (data during 1995-2015), whereas the growing season lasts from 210 to 220 days per calendar year (Jagodziński et al. 2018). The undergrowth vegetation on the spoil heap plots was composed mainly of Calamagrostis epigejos (L.) Roth, Festuca pratensis Huds. and Festuca rubra L. (Rawlik et al. 2018a, b), whereas the undergrowth on research plots located on the adjacent forest area was composed of Carex ovalis Good., Vaccinium myrtillus L. and Moehringia trinervia (L.) Clairv. (Urbanowski et al. 2018).

The decomposition experiment began in 2011 and lasted 5 years (2011-2016). All the litter that was inside the litterbags was collected ex-situ during autumn of the same year, but still on the spoil heap area. The litter used was oven-dried and weighed and then placed in litterbags of fiberglass fabric $(1 \mathrm{~mm}$ mesh size, $15 \times 15 \mathrm{~cm})$ on the 11 research plotsthree plots in mixed stands on the spoil heap, two plots in monoculture Scots pine stands and two in silver birch stands on the spoil heap, and two plots in monoculture Scots pine stands and two in silver birch stands on the forest area. All samples were randomly laid out in December 2011 and collected after 91, 182, 275, 366, 548, 730, 913, 1100 days in monoculture stands, as well as after 95, 196, 285, 385, 564, 753, 936, 1117, 1298 and 1754 days in mixed stands. Single-species stands growing on the spoil heap and forest areas were covered by Pinus sylvestris L. and Betula pendula Roth, wherea all mixed stands were covered mostly by B. pendula, Larix decidua Mill., Pinus nigra Arn., P. sylvestris and Robinia pseudoacacia L. (for more basic plot characteristics see Urbanowski et al. 2018, 2021). In mixed stands litterbags contained single-species litter of Acer pseudoplatanus L., A. glutinosa, B. pendula, Fagus sylvatica L., Fraxinus excelsior L., P. sylvestris, Populus nigra L. 'Italica', Populus tremula L., Populus $\times$ canadensis Moench, Prunus serotina Ehrh., Quercus robur L., Quercus rubra L., R. pseudoacacia and Ulmus laevis Pall., whereas in monoculture stands: Alnus glutinosa (L.) Gaertn., B. pendula, P. sylvestris and $Q$. robur, and only these four litter species were analized in the mixed stands in the habitat type experiment. In total, 2413 litterbag samples were laid out; however, as a result of random external factors (e.g., litterbag destruction by wildlife), 28 samples were excluded from further analysis. After sampling, litterbags were transported to the Department of Game Management and Forest Protection laboratory (Poznań University of Life Sciences, Poznań, Poland) in order to isolate the soil fauna (see below), then oven-dried at $65^{\circ} \mathrm{C}$ to 
a constant dry mass to estimate the initial dry litter mass and percentage litter mass loss. Additionally, on the research plots in mixed stands, the soil mean temperature was measured using HOBO U23 Pro v.2 data loggers (1-h measurement intervals; located around $3 \mathrm{~cm}$ beneath the mineral soil surface).

\section{Mesostigmata investigation}

Soil fauna was extracted from litterbags using Berlese-Tullgren funnels ( $2 \mathrm{~mm}$ mesh size) for a minimum of 6 days (constant temperature in funnels near samples: $30 \pm 0.5^{\circ} \mathrm{C}$ ), until the collected samples were dry. The changing moisture and temperature gradient in the funnels forced soil fauna to migrate directly down to the containers with $75 \%$ ethyl alcohol. After the extraction process, mesostigmatid mites were selected using a stereomicroscope, then mounted on slides in $85 \%$ lactic acid for a minimum of 3 days to ensure maximum transparency of selected specimens. Afterwards, mites were identified to the genus and/or species level, including developmental stages, using acarological keys (i.e., Micherdziński 1969; Karg 1971, 1993; Giljarov and Bregetova 1977; Gwiazdowicz 2007).

\section{Statistical analysis}

To keep comparability, all integer values were calculated to mean values followed by the standard deviation (SD). We calculated the mean number of mite specimens per plot, litter type and collection date to reduce the number of replications per variant. Mean mite abundance was calculated per $100 \mathrm{~g}$ of dry litter mass. To compare the mutual relationships of mite developmental stages (females per male; juveniles per female) between habitat and litter types we used the HSD.test function from the agricolae package (de Mendiburu 2013). The mutual relationships were calculated based on total abundance. Furthermore, we analyzed 'collection date' and 'plot selection' as random effects. Models (backward model selection) were developed using the lme4 package (Bates et al. 2015). We applied predictors with low variance inflation factors $(\mathrm{VIF}<3)$. Moreover, as was supported by overdispersion which can be detected by dividing the residual deviance by the degrees of freedom, we applied negative binomial distributions for each developmental stage and used generalized linear mixed models (GLMM). Moreover, we also included a quadratic term for soil mean temperature in the litter type experiment to allow for a nonlinear relationship in models of mean abundance of males and juveniles, as supported by the improvement of the model AICc scores (males, AICc $=-1.04$; juveniles, $\mathrm{AICc}=-1.84$ ). The statistical significance of variables used in models (habitat type, litter type, collection date, percentage litter mass loss and soil mean temperature) was calculated using z-values, implemented in the lmerTest package (Kuznetsova et al. 2017). Additionally, Tukey post-hoc tests were done to determine the differences between the litter and habitat types studied. Statistical analyses were done using R software (https://www.Rproject.org/).

\section{Results}

In total (habitat and litter type experiments), we recorded 25,763 mites indicated as 81 taxa (77 species and four genera; Appendix 1). Moreover, generalized linear mixed models (assuming negative binomial distributions) explaining mean female, male and juvenile 
abundances per dry litter mass within experiments indicated no statistical influence of collection date on any mite developmental stage (Table 1).

\section{Mite instars among habitat types}

In the habitat type experiment we found 12,145 specimens (6395 females, 855 males and 4895 juveniles). For each developmental stage we found that habitat type significantly affected mite assemblages. Moreover, taking into account habitat type, the percentage litter mass loss also significantly affected mite assemblages, except for juvenile stages (Table 1).

The highest mean female abundance was found in FHbirch $(550.09 \pm 444.14$ specimens), whereas the lowest was found in SHpine (24.10 \pm 25.55$)$. Mean female abundance differed significantly between those habitats (Tukey test: $\mathrm{P}<0.0001$ ). Interestingly, the mean female abundance recorded in SHmixed (217.66 237.38 specimens) differed significantly only from SHpine (Tables 2 and 3). The mean female abundance was highest at 1100 days after the start of the experiment in FHbirch (1204.44 \pm 416.25 specimens), on day 730 in SHbirch (317.28 \pm 309.24$)$, and on day 1754 in SHmixed (740.41 \pm 471.20$)$. The highest mean female abundances in monoculture pine stands were recorded on day 275 (FHpine, 446.40 \pm 16.52; SHpine, 70.30 \pm 10.84 ) (Appendix 2).

The mean male abundances were highest in FHbirch (90.44 \pm 86.89 specimens), and lowest in SHpine $(6.47 \pm 7.75)$. Mean male abundance recorded in FHbirch differed significantly from each habitat type examined in terms of mean male abundance (Tables 2 and 3). The mean male abundances were highest 730 days after the experiment started on the forest area (FHbirch, 227.06 \pm 123.42 ; FHpine, 58.70 \pm 51.51 ). On the spoil heap area the highest values of mean male abundance were recorded after 275 days (SHbirch, $53.20 \pm 27.97$; SHpine, $21.88 \pm 1.19$ ). In SHmixed the highest values of mean male abundance were obtained after 1754 days $(44.70 \pm 30.13)$ at the end of experiment (Appendix 2).

The mean juvenile abundance was highest in FHbirch $(303.02 \pm 211.02$ specimens). However, we also recorded high mean abundance of juvenile mites in SHmixed $(212.83 \pm 269.76)$, when compared to the lowest values recorded in SHbirch $(8.22 \pm 14.82)$ and SHpine $(8.13 \pm 14.48)$. Mean juvenile abundances recorded in FHpine (98.16 \pm 91.42$)$, as well as FHbirch and SHmixed, differed significantly from monoculture stands growing on the spoil heap $(\mathrm{P}<0.0001)$ (Tables 2 and 3$)$. The mean juvenile abundance was highest on day 1100 in FHbirch $(721.93 \pm 94.03)$. On the same day we recorded the highest value of mean juvenile abundance in FHpine $(213.10 \pm 25.72)$. On the spoil heap area, the juvenile mites reached the highest mean abundances after 275 days in SHbirch $(43.55 \pm 16.81)$ and SHpine $(40.02 \pm 15.25)$, as well as after 936 days in SHmixed $(574.36 \pm 422.52)$ (Appendix 2).

The analysis of mutual instar relationships showed that the mean number of juvenile instars per female was the lowest in SHbirch $(0.09 \pm 0.14)$. Furthermore, the mean number of females per male was the lowest in SHpine (2.46 \pm 2.36$)$; however, the mean number of females per male was similar on each habitat type studied (Tukey test: $\mathrm{P}>0.05$ ). Moreover, the mean number of juvenile instars per female differed significantly between habitat types examined (Table 4).

The analysis of mite developmental stages on the species-level for the most dominant mite species revealed that juveniles of Trachytes aegrota recorded in SHmixed constituted the majority of individuals of this mite species (55.1\% of total abundance). Also abundant were females of this mite species in the same habitat type $(26.7 \%$ of total 
Table 1 Generalized linear mixed models assuming negative binomial distribution explaining mean female, male and juvenile abundances per $100 \mathrm{~g}$ dry litter mass within experiments

\begin{tabular}{|c|c|c|c|c|c|}
\hline Response & Term & Estimate & SE & $\mathrm{z}$ & $\operatorname{Pr}(>|z|)$ \\
\hline \multicolumn{6}{|l|}{ HTexp } \\
\hline \multirow[t]{8}{*}{ Females } & (Intercept) & 4.4931 & 0.6859 & 6.5510 & $<0.0001$ \\
\hline & FHpine & -1.3923 & 0.3790 & -3.6740 & $<0.0001$ \\
\hline & SHmixed & -0.8118 & 0.5369 & -1.5120 & 0.13 \\
\hline & SHbirch & -1.8930 & 0.3878 & -4.8810 & $<0.0001$ \\
\hline & SHpine & -3.1642 & 0.3919 & -8.0740 & $<0.0001$ \\
\hline & plml & 0.0269 & 0.0096 & 2.8020 & 0.0051 \\
\hline & Random effect—collection date & Variance & 0.8931 & SD & 0.9451 \\
\hline & Random effect—plot & Variance & $<0.0001$ & SD & $<0.0001$ \\
\hline \multirow[t]{8}{*}{ Males } & (Intercept) & 3.4497 & 0.5933 & 5.8140 & $<0.0001$ \\
\hline & FHpine & -1.4147 & 0.4260 & -3.3210 & $<0.0001$ \\
\hline & SHmixed & -1.8366 & 0.4794 & -3.8310 & $<0.0001$ \\
\hline & SHbirch & -2.3448 & 0.4620 & -5.0760 & $<0.0001$ \\
\hline & SHpine & -2.8060 & 0.4472 & -6.2750 & $<0.0001$ \\
\hline & plml & 0.0176 & 0.0084 & 2.0890 & 0.037 \\
\hline & Random effect—collection date & Variance & 0.4501 & SD & 0.6709 \\
\hline & Random effect—plot & Variance & $<0.0001$ & $\mathrm{SD}$ & $<0.0001$ \\
\hline \multirow[t]{8}{*}{ Juveniles } & (Intercept) & 4.4240 & 0.7844 & 5.6400 & $<0.0001$ \\
\hline & FHpine & -1.1846 & 0.4978 & -2.3800 & 0.017 \\
\hline & SHmixed & -0.7614 & 0.6397 & -1.1900 & 0.23 \\
\hline & SHbirch & -3.9030 & 0.5201 & -7.5040 & $<0.0001$ \\
\hline & SHpine & -4.0396 & 0.5212 & -7.7510 & $<0.0001$ \\
\hline & plml & 0.0207 & 0.0109 & 1.9030 & 0.057 \\
\hline & Random effect—collection date & Variance & 1.0271 & SD & 1.0135 \\
\hline & Random effect—plot & Variance & 0.0618 & SD & 0.2486 \\
\hline \multicolumn{6}{|l|}{ Ltexp } \\
\hline \multirow[t]{18}{*}{ Females } & (Intercept) & 3.8179 & 0.4965 & 7.6900 & $<0.0001$ \\
\hline & Aln_glu & -0.3666 & 0.2484 & -1.4760 & 0.14 \\
\hline & Bet_pen & -0.1332 & 0.2501 & -0.5330 & 0.59 \\
\hline & Fag_syl & -0.3480 & 0.2777 & -1.2530 & 0.21 \\
\hline & Fra_exc & -0.1093 & 0.2488 & -0.4390 & 0.66 \\
\hline & Pin_syl & -0.2590 & 0.2613 & -0.9910 & 0.32 \\
\hline & Pop_can & -0.0426 & 0.2504 & -0.1700 & 0.86 \\
\hline & Pop_nig & -0.4801 & 0.2582 & -1.8590 & 0.063 \\
\hline & Pop_tre & -0.0233 & 0.2477 & -0.0940 & 0.93 \\
\hline & Pru_ser & -0.3116 & 0.2565 & -1.2150 & 0.22 \\
\hline & Que_rob & -0.5071 & 0.2862 & -1.7720 & 0.076 \\
\hline & Que_rub & -0.1852 & 0.2583 & -0.7170 & 0.47 \\
\hline & Rob_pse & -0.2245 & 0.2628 & -0.8540 & 0.39 \\
\hline & Ulm_lae & 0.3933 & 0.2529 & 1.5550 & 0.12 \\
\hline & smt & 0.0651 & 0.0364 & 1.7880 & 0.074 \\
\hline & plml & 0.0174 & 0.0043 & 4.0080 & $<0.0001$ \\
\hline & Random effect-collection date & Variance & 0.2393 & SD & 0.4891 \\
\hline & Random effect—plot & Variance & 0.0893 & SD & 0.2989 \\
\hline
\end{tabular}


Table 1 (continued)

\begin{tabular}{|c|c|c|c|c|c|}
\hline Response & Term & Estimate & SE & $\mathrm{z}$ & $\operatorname{Pr}(>|z|)$ \\
\hline \multirow{19}{*}{ Males } & (Intercept) & 1.2093 & 0.5662 & 2.1360 & 0.033 \\
\hline & Aln_glu & -0.6540 & 0.5078 & -1.2880 & 0.20 \\
\hline & Bet_pen & -0.3192 & 0.4995 & -0.6390 & 0.52 \\
\hline & Fag_syl & -0.2400 & 0.5221 & -0.4600 & 0.65 \\
\hline & Fra_exc & -0.2935 & 0.5101 & -0.5750 & 0.57 \\
\hline & Pin_syl & -0.7689 & 0.5064 & -1.5180 & 0.13 \\
\hline & Pop_can & -0.2710 & 0.5101 & -0.5310 & 0.60 \\
\hline & Pop_nig & -0.9187 & 0.5077 & -1.8100 & 0.070 \\
\hline & Pop_tre & 0.1968 & 0.5149 & 0.3820 & 0.70 \\
\hline & Pru_ser & -0.0965 & 0.5250 & -0.1840 & 0.85 \\
\hline & Que_rob & -0.8703 & 0.5253 & -1.6570 & 0.098 \\
\hline & Que_rub & -0.7701 & 0.5111 & -1.5070 & 0.13 \\
\hline & Rob_pse & -0.2462 & 0.5094 & -0.4830 & 0.63 \\
\hline & Ulm_lae & -0.2629 & 0.5157 & -0.5100 & 0.61 \\
\hline & $\mathrm{smt}$ & 0.3264 & 0.1301 & 2.5100 & 0.012 \\
\hline & $s m t^{\wedge} 2$ & -0.0148 & 0.0073 & -2.0290 & 0.042 \\
\hline & plml & 0.0097 & 0.0050 & 1.9440 & 0.052 \\
\hline & Random effect-collection date & Variance & 0.0509 & SD & 0.2257 \\
\hline & Random effect—plot & Variance & $<0.0001$ & SD & $<0.0001$ \\
\hline \multirow[t]{19}{*}{ Juveniles } & (Intercept) & 1.2617 & 0.6314 & 1.9980 & 0.046 \\
\hline & Aln_glu & -0.3039 & 0.3255 & -0.9340 & 0.35 \\
\hline & Bet_pen & -0.6707 & 0.3246 & -2.0660 & 0.039 \\
\hline & Fag_syl & -0.6718 & 0.3576 & -1.8790 & 0.060 \\
\hline & Fra_exc & -0.4426 & 0.3240 & -1.3660 & 0.17 \\
\hline & Pin_syl & -0.3378 & 0.3356 & -1.0060 & 0.31 \\
\hline & Pop_can & -0.1222 & 0.3255 & -0.3750 & 0.71 \\
\hline & Pop_nig & -0.3990 & 0.3388 & -1.1780 & 0.24 \\
\hline & Pop_tre & 0.1984 & 0.3269 & 0.6070 & 0.54 \\
\hline & Pru_ser & -0.0966 & 0.3326 & -0.2910 & 0.77 \\
\hline & Que_rob & -0.6927 & 0.3651 & -1.8970 & 0.058 \\
\hline & Que_rub & -0.4820 & 0.3314 & -1.4550 & 0.15 \\
\hline & Rob_pse & -0.5932 & 0.3368 & -1.7610 & 0.078 \\
\hline & Ulm_lae & -0.0045 & 0.3243 & -0.0140 & 0.99 \\
\hline & smt & 0.5124 & 0.1336 & 3.8370 & $<0.0001$ \\
\hline & $\operatorname{smt}^{\wedge} 2$ & -0.0183 & 0.0076 & -2.4120 & 0.016 \\
\hline & plml & 0.0197 & 0.0049 & 3.9870 & $<0.0001$ \\
\hline & Random effect-collection date & Variance & 0.1181 & $\mathrm{SD}$ & 0.3436 \\
\hline & Random effect—plot & Variance & 0.4708 & SD & 0.6861 \\
\hline
\end{tabular}

HTexp habitat type experiment, LTexp litter type experiment, plml percentage litter mass loss, smt soil mean temperature 
Table 2 Tukey post-hoc tests conducted for habitat type in models assuming negative binomial distribution for mean female, male and juvenile abundances calculated per $100 \mathrm{~g}$ dry litter mass

\begin{tabular}{llllllr}
\hline Response & Term & Estimate & SE & Df & z ratio & p \\
\hline Females & FHbirch - FHpine & 1.392 & 0.379 & Inf & 3.674 & 0.0024 \\
& FHbirch - SHbirch & 1.893 & 0.388 & Inf & 4.881 & $<0.0001$ \\
& FHbirch - SHpine & 3.164 & 0.392 & Inf & 8.074 & $<0.0001$ \\
& FHpine - SHpine & 1.772 & 0.351 & Inf & 5.046 & $<0.0001$ \\
& SHmixed - SHpine & 2.352 & 0.552 & Inf & 4.260 & 0.0002 \\
Males & SHbirch - SHpine & 1.271 & 0.339 & Inf & 3.745 & 0.0018 \\
& FHbirch - FHpine & 1.415 & 0.426 & Inf & 3.321 & 0.0090 \\
& FHbirch - SHmixed & 1.837 & 0.479 & Inf & 3.831 & 0.0013 \\
& FHbirch - SHbirch & 2.345 & 0.462 & Inf & 5.076 & $<0.0001$ \\
& FHbirch - SHpine & 2.806 & 0.447 & Inf & 6.275 & $<0.0001$ \\
& FHpine - SHpine & 1.391 & 0.411 & Inf & 3.388 & 0.0070 \\
& FHbirch - SHbirch & 3.903 & 0.520 & Inf & 7.504 & $<0.0001$ \\
& FHbirch - SHpine & 4.04 & 0.521 & Inf & 7.751 & $<0.0001$ \\
& FHpine - SHbirch & 2.718 & 0.494 & Inf & 5.500 & $<0.0001$ \\
& FHpine - SHpine & 2.855 & 0.487 & Inf & 5.860 & $<0.0001$ \\
& SHmixed - SHbirch & 3.142 & 0.660 & Inf & 4.762 & $<0.0001$ \\
& SHmixed - SHpine & 3.278 & 0.662 & Inf & 4.952 & $<0.0001$ \\
\hline & & & & & &
\end{tabular}

FHbirch monoculture stands of silver birch growing on forest habitat, FHpine monoculture stands of Scots pine growing on forest habitat, SHmixed mixed stands growing on spoil heap, SHbirch monoculture stands of silver birch growing on spoil heap, SHpine monoculture stands of Scots pine growing on spoil heap, Inf infinity

Table 3 Mean $( \pm$ SD) female, male and juvenile abundances per $100 \mathrm{~g}$ dry litter mass recorded within habitat types

\begin{tabular}{lccc}
\hline Habitat type & Females & Males & Juveniles \\
\hline FHbirch & $550.09 \pm 444.14$ & $90.44 \pm 86.89$ & $303.02 \pm 211.02$ \\
FHpine & $136.10 \pm 147.83$ & $23.16 \pm 27.44$ & $98.16 \pm 91.42$ \\
SHmixed & $217.66 \pm 237.38$ & $16.19 \pm 15.31$ & $212.83 \pm 269.76$ \\
SHbirch & $119.59 \pm 155.74$ & $10.5 \pm 18.74$ & $8.22 \pm 14.82$ \\
SHpine & $24.10 \pm 25.55$ & $6.47 \pm 7.75$ & $8.13 \pm 14.48$ \\
\hline
\end{tabular}

FHbirch monoculture stands of silver birch growing on forest habitat, FHpine monoculture stands of Scots pine growing on forest habitat, SHmixed mixed stands growing on spoil heap, SHbirch monoculture stands of silver birch growing on spoil heap, SHpine monoculture stands of Scots pine growing on spoil heap

abundance). Interestingly, females and juveniles of Veigaia nemorensis and Zercon peltatus were the most abundant in forest areas. Equally numerous occurrences of females and juveniles of $V$. nemorensis were also recorded in SHmixed (females, 24.0\% of total abundance; juveniles, 11.9\%) (Table 5). 
Table 4 Mutual relationships of mite developmental stages recorded within habitat types (data presented as mean values $\pm \mathrm{SD}$ )

\begin{tabular}{lclll}
\hline Habitat type & Females per male & Females/male [\%] & Juveniles per female & Juveniles/female [\%] \\
\hline FHbirch & $13.18 \pm 12.54 \mathrm{a}$ & $81.37 \pm 23.77 \mathrm{ab}$ & $0.74 \pm 0.44 \mathrm{abc}$ & $39.61 \pm 12.49 \mathrm{a}$ \\
FHpine & $9.31 \pm 16.53 \mathrm{a}$ & $69.53 \pm 36.06 \mathrm{ab}$ & $0.93 \pm 1.08 \mathrm{ab}$ & $40.22 \pm 31.89 \mathrm{a}$ \\
SHmixed & $12.39 \pm 8.23 \mathrm{a}$ & $92.19 \pm 4.94 \mathrm{a}$ & $0.94 \pm 0.89 \mathrm{a}$ & $39.42 \pm 22.30 \mathrm{a}$ \\
SHbirch & $11.27 \pm 17.32 \mathrm{a}$ & $58.74 \pm 43.17 \mathrm{~b}$ & $0.09 \pm 0.14 \mathrm{c}$ & $13.35 \pm 25.09 \mathrm{~b}$ \\
SHpine & $2.46 \pm 2.36 \mathrm{a}$ & $61.25 \pm 37.55 \mathrm{~b}$ & $0.30 \pm 0.35 \mathrm{bc}$ & $18.51 \pm 18.89 \mathrm{ab}$ \\
\hline
\end{tabular}

FHbirch monoculture stands of silver birch growing on forest habitat, FHpine monoculture stands of Scots pine growing on forest habitat, SHmixed mixed stands growing on spoil heap, SHbirch monoculture stands of silver birch growing on spoil heap, SHpine monoculture stands of Scots pine growing on spoil heap

Means within a column followed by different letters are significantly different (Tukey post hoc test: $\mathrm{P}<0.05)$

Table 5 Mite developmental stages share [\%] on the specieslevel for the most dominant mite species (see Appendix 1) recorded within habitat types (data based on total abundance of a given mite species)

\begin{tabular}{|c|c|c|c|}
\hline \multirow[t]{2}{*}{ Habitat type } & \multicolumn{3}{|l|}{ Mite species } \\
\hline & Trachytes aegrota & Zercon peltatus & $\begin{array}{l}\text { Veigaia } \\
\text { nemoren- } \\
\text { sis }\end{array}$ \\
\hline \multicolumn{4}{|l|}{ FHbirch } \\
\hline Females & 8.96 & 22.30 & 31.03 \\
\hline Males & 0 & 14.07 & 0 \\
\hline Juveniles & 8.27 & 9.60 & 24.78 \\
\hline \multicolumn{4}{|l|}{ FHpine } \\
\hline Females & 0.38 & 29.40 & 3.59 \\
\hline Males & 0 & 2.28 & 0 \\
\hline Juveniles & 0.46 & 21.56 & 4.60 \\
\hline \multicolumn{4}{|l|}{ SHmixed } \\
\hline Females & 26.74 & 0.04 & 23.99 \\
\hline Males & 0 & 0 & 0 \\
\hline Juveniles & 55.09 & 0.00 & 11.93 \\
\hline \multicolumn{4}{|l|}{ SHbirch } \\
\hline Females & 0 & 0.18 & 0 \\
\hline Males & 0 & 0 & 0 \\
\hline Juveniles & 0 & 0.13 & 0 \\
\hline \multicolumn{4}{|l|}{ SHpine } \\
\hline Females & 0 & 0.22 & 0 \\
\hline Males & 0 & 0.04 & 0 \\
\hline Juveniles & 0.10 & 0.18 & 0.07 \\
\hline
\end{tabular}

FHbirch monoculture stands of silver birch growing on forest habitat, FHpine monoculture stands of Scots pine growing on forest habitat, SHmixed mixed stands growing on spoil heap, SHbirch monoculture stands of silver birch growing on spoil heap, SHpine monoculture stands of Scots pine growing on spoil heap 


\section{Mite instars among litter types}

In the litter type experiment we found 19,296 specimens (9198 females, 832 males, 9266 juveniles). Interestingly, the generalized linear mixed model that explained mean juvenile abundance per dry litter mass indicated a significant influence of litter type. Furthermore, percentage litter mass loss significantly affected the mean abundances of female and juvenile developmental stages. Also, the soil mean temperature had a significant effect on mean male and juvenile abundances, but not on females (Table 1). Tukey tests conducted for the litter type experiment in models (assuming negative binomial distributions) for mean female, male and juvenile abundances calculated per $100 \mathrm{~g}$ dry litter mass indicated that there were no significant differences in each developmental stage.

The highest mean female abundance was found in $U$. laevis litter $(522.75 \pm 859.15$ specimens), whereas the lowest was in $Q$. robur $(117.93 \pm 132.64)$ (Table 6). The highest mean female abundances for each litter type were found after 1754 days (10 litter types) and 1298 days (three litter types) since the experiment started. Only in P. serotina litter $(722.34 \pm 1190.74)$ was the mean female abundance highest after 1117 days. Interestingly, there were no female mites in $P$. serotina after 936 days. On the same day the lowest mean female abundance for $P . \times$ canadensis litter $(14.11 \pm 6.31)$ was recorded; however, the remainder of litter types had the lowest mean female abundances at the first collection date, 95 days since the experiment started (Appendix 3).

The highest mean male abundance was found in $P$. tremula litter $(53.66 \pm 208.96 \mathrm{spec}-$ imens), whereas the lowest was in $Q$. robur $(9.99 \pm 15.40)$ (Table 6). The highest mean male abundances for each litter type were found at 1754 (five litter types), 1298 (three litter types) and 1117 days (four litter types) since the experiment started. In $F$. sylvatica litter, the highest mean male abundance $(38.97 \pm 22.28)$ was recorded after 285 days, whereas for $U$. laevis $(78.05 \pm 85.95)$ it was recorded after 936 days. The mean male abundance was highest at day 1754 in $P$. tremula litter (383.14 \pm 663.62$)$, whereas there were no male mites at the first collection date (day 95) in P. nigra, $P$. serotina and $Q$. rubra litter.

Table 6 Mean $( \pm$ SD) female, male and juvenile abundances per $100 \mathrm{~g}$ dry litter mass recorded within 14 litter types

\begin{tabular}{llll}
\hline Litter type & Females & Males & Juveniles \\
\hline Ace_pse & $305.99 \pm 250.89$ & $30.68 \pm 52.68$ & $354.87 \pm 472.48$ \\
Aln_glu & $255.32 \pm 331.24$ & $19.35 \pm 44.27$ & $314.17 \pm 533.62$ \\
Bet_pen & $277.72 \pm 536.41$ & $20.15 \pm 24.46$ & $181.89 \pm 296.26$ \\
Fag_syl & $120.15 \pm 93.52$ & $16.61 \pm 21.31$ & $98.61 \pm 106.43$ \\
Fra_exc & $300.81 \pm 222.18$ & $20.48 \pm 31.70$ & $300.47 \pm 459.92$ \\
Pin_syl & $165.95 \pm 115.50$ & $12.53 \pm 15.84$ & $179.71 \pm 192.17$ \\
Pop_can & $344.83 \pm 736.88$ & $18.86 \pm 51.40$ & $238.55 \pm 451.66$ \\
Pop_nig & $154.87 \pm 144.44$ & $10.54 \pm 12.40$ & $144.73 \pm 155.81$ \\
Pop_tre & $319.74 \pm 432.16$ & $53.66 \pm 208.96$ & $512.00 \pm 1083.18$ \\
Pru_ser & $271.79 \pm 427.07$ & $31.87 \pm 93.60$ & $499.81 \pm 1260.48$ \\
Que_rob & $117.93 \pm 132.64$ & $9.99 \pm 15.40$ & $118.05 \pm 163.26$ \\
Que_rub & $192.36 \pm 168.18$ & $11.89 \pm 13.23$ & $153.54 \pm 162.67$ \\
Rob_pse & $160.58 \pm 122.64$ & $19.58 \pm 20.27$ & $124.21 \pm 126.55$ \\
Ulm_lae & $522.75 \pm 859.15$ & $20.34 \pm 35.33$ & $330.68 \pm 399.59$ \\
\hline
\end{tabular}

Litter types are abbreviated to the first three letters of genera name and first three letters of the species name 
Likewise, there were no male mites in A. pseudoplatanus (day 1754), A. glutinosa (936, 1117 and 1298), F. excelsior $(1117,1754)$, P. $\times$ canadensis $(936,1298)$, P. serotina $(936$, 1298), Q. rubra (753), and U. laevis litter (1298) (Appendix 3).

The highest mean juvenile abundance was found in $P$. tremula litter $(512.00 \pm 1083.18$ specimens), whereas the lowest was in $F$. sylvatica $(98.61 \pm 106.43)$. Interestingly, in $P$. serotina litter we also found very high mean juvenile abundance $(499.81 \pm 1260.48)$, when compared to other litter types examined (Table 6). The highest mean values of juvenile abundance for each litter type were found on days 936 (five litter types), 1117 (three litter types), 564 (two litter types) and 196 (two litter types) since the experiment started. Moreover, in $Q$. rubra $(305.40 \pm 129.60)$ and $U$. laevis litter $(761.91 \pm 681.43)$ we recorded the highest mean juvenile abundances at 1298 and 1754 days, respectively. The mean juvenile abundance was highest on day 1117 in $P$. serotina litter $(2172.53 \pm 3762.94)$. All the litter types examined had the lowest mean juvenile abundances on the first collection date (day 95); however, the lowest were recorded on day 95 in B. pendula $(1.21 \pm 2.09)$ and $Q$. robur litter (1.59 \pm 2.76$)$ (Appendix 3).

The analysis of mutual instar relationships showed that the mean number of females per male was highest in $P$. sylvestris litter $(9.08 \pm 10.53$ specimens $)$. The lowest value was recorded in $P$. serotina $(3.32 \pm 5.77)$. However, an equally high value of the mean number of females per male was recorded in $R$. pseudoacacia litter $(9.08 \pm 9.18)$. Moreover, we found that the highest number of juveniles per female was in A. glutinosa litter $(1.66 \pm 3.87)$, whereas the lowest was in B. pendula $(0.71 \pm 0.83)$. Tukey tests conducted for mutual instar relationships, indicated no significant differences among litter types. The percentage of females to males for each litter type was $>75(78.4 \pm 36.5-92.7 \pm 7.9 \%)$, whereas the percentage of juveniles to females remained stable $(34.7 \pm 25.9-45.6 \pm 28.9 \%)$ (Table 7).

Table 7 Mutual relationships of mite developmental stages recorded within litter types (data presented as mean values $\pm \mathrm{SD}$ )

\begin{tabular}{lllll}
\hline Litter type & Females per Male & Females/Male [\%] & Juveniles per Female & Juveniles/Female [\%] \\
\hline Ace_pse & $8.60 \pm 14.22$ & $86.32 \pm 23.30$ & $1.26 \pm 1.50$ & $41.00 \pm 27.20$ \\
Aln_glu & $7.62 \pm 11.44$ & $85.67 \pm 29.77$ & $1.66 \pm 3.87(\mathrm{a})$ & $39.17 \pm 31.52$ \\
Bet_pen & $8.13 \pm 9.73$ & $87.28 \pm 17.98$ & $0.71 \pm 0.83$ & $34.71 \pm 25.90$ \\
Fag_syl & $7.19 \pm 10.95$ & $86.05 \pm 19.64$ & $0.88 \pm 0.77$ & $38.13 \pm 23.18$ \\
Fra_exc & $4.56 \pm 5.58$ & $85.07 \pm 25.73$ & $0.96 \pm 1.27$ & $35.00 \pm 26.21$ \\
Pin_syl & $9.08 \pm 10.53$ & $92.67 \pm 7.93$ & $0.91 \pm 0.86$ & $38.06 \pm 23.26$ \\
Pop_can & $7.62 \pm 10.54$ & $89.94 \pm 19.72$ & $1.24 \pm 2.70$ & $36.98 \pm 24.50$ \\
Pop_nig & $6.92 \pm 8.07$ & $92.27 \pm 8.44$ & $1.52 \pm 2.67$ & $39.61 \pm 27.98$ \\
Pop_tre & $7.57 \pm 11.90$ & $87.70 \pm 21.56$ & $1.02 \pm 1.24$ & $40.04 \pm 27.75$ \\
Pru_ser & $3.32 \pm 5.77$ & $78.44 \pm 36.50$ & $0.86 \pm 1.03$ & $36.57 \pm 28.88$ \\
Que_rob & $5.25 \pm 7.87$ & $82.27 \pm 29.40$ & $1.14 \pm 1.57$ & $42.90 \pm 31.04$ \\
Que_rub & $6.86 \pm 8.22$ & $91.53 \pm 12.20$ & $0.84 \pm 1.00$ & $34.76 \pm 23.86$ \\
Rob_pse & $9.08 \pm 9.18$ & $84.03 \pm 19.86$ & $1.00 \pm 1.30$ & $36.44 \pm 24.02$ \\
Ulm_lae & $7.93 \pm 7.78$ & $83.84 \pm 29.18$ & $0.92 \pm 1.10$ & $45.55 \pm 28.95$ \\
\hline
\end{tabular}

Litter types are abbreviated to the first three letters of genera name and first three letters of the species name Means within a column were not significantly different (Tukey post hoc test: $\mathrm{P}>0.05$ ) 


\section{Discussion}

\section{Successive changes of gamasid instars and habitat influence on mite communities}

Various methods have been used in decomposition studies, but the use of litterbags has recently become one of the most common methods (Kampichler and Bruckner 2009; Urbanowski et al. 2018, 2021; Horodecki et al. 2019; Kamczyc et al. 2019). The litterbag method is a minimally invasive method for soil fauna. Litterbags made of fiberglass fabric, which we used in our research, can also affect edaphone communities. The mesh size of litterbags may determine the conditions inside. Litterbags with smaller meshes could be characterized by increased humidity inside the bag and exclude free access of larger soil fauna to the decomposed organic matter contained in the bag (Kampichler and Bruckner 2009). The fact that we have found mites from the Mesostigmata order, both smaller $(<1 \mathrm{~mm}$ body length) and larger $(>1 \mathrm{~mm})$ indicates a correctly adopted litterbag experiment methodology (Kampichler and Bruckner 2009; Urbanowski et al. 2018, 2021; Horodecki et al. 2019).

Many studies have shown that environmental conditions (post-mining vs. forest areas) significantly shape soil fauna communities, including mites (Skubała 2002a; Murvanidze et al. 2013; Urbanowski et al. 2018). Moreover, the positive effect of mixed stands on soil fauna is well known (Irmler 2000; Elmer et al. 2004; Cesarz et al. 2007; Cavard et al. 2011; Korboulewsky et al. 2016; Horodecki et al. 2019; Urbanowski et al. 2021). Compared to monocultures, mixed stands are often characterized by greater biodiversity and better conditions (smaller fluctuations of humidity and temperature fluctuations) for the proper development of soil organisms (Cavard et al. 2011; Korboulewsky et al. 2016; Horodecki et al. 2019; Urbanowski et al. 2021). Interestingly, in our results the highest mean female, male and juvenile abundances were recorded in FHbirch. This confirms the results of Skorupski (2010), who found that silver birch plots had the highest number of species and one of the highest abundances of soil Mesostigmata mites among the 14 tree species of a commongarden experiment; furthermore, the abundances were also higher than on the Scots pine plots. Juvenile mites were also highly numerous in SHmixed.

The reproductive abilities are strongly related to environmental factors (Polis and Strong 1996; Błoszyk et al. 2004). Therefore, in unstable environmental conditions, such as postmining spoil heaps, species inhabiting this environment may try to maximize reproductive effort by increasing abundance of females, which results in a high number of juvenile stages in communities (Polis and Strong 1996; Napierała and Błoszyk 2013). The high abundance of juveniles in unstable habitat conditions may also result from parthenogenetic reproduction of species (Norton et al. 1993; Błoszyk et al. 2004). On the other hand, Błoszyk et al. (2004) stated that in more stable environments, such as forest litter and soil, parthenogenetic mesostigmatid taxa were more abundant compared to bisexual mite taxa which inhabited more temporary microhabitats. We found that females and juveniles of $T$. aegrota in SHmixed constituted the majority of individuals of this mite species. Błoszyk et al. (2004) stated that this species is a common parthenogenetic mite taxon. Madej and Skubała (1996) and Urbanowski et al. (2021) recorded this species frequently on postindustrial areas. However, some authors stated that this mite species is typical for forest areas (Pastwik et al. 2013; Piasta et al. 2015). Interestingly, we found a high percentage share of females and juveniles of $V$. nemorensis, a typically parthenogenetic mite species (Alberti et al. 2010), in forest areas and in mixed stands growing on the spoil heap. The importance of parthenogenetic mite species in the colonization of habitat-diversified areas 
is still difficult to estimate (Norton et al. 1993; Madej and Skubała 2002; Błoszyk et al. 2004), even more so in post-industrial areas (Madej and Skubała 2002). Nevertheless, our results show that the spoil heap (especially mixed stands) and forest area were characterized by a high abundance of parthenogenetic mesostigmatid species.

The mean abundance recorded for all instars examined was lowest in the SHpine, which supports our assumptions about the positive effect of mixed stands on development of gamasid mite assemblages in comparison to monoculture stands. The number of juvenile instars in relation to older developmental stages determines the stability of the community structure living in a given area and significantly depends on environmental conditions (Miller and Rudolf 2011; Tuka and Solarz 2017); therefore, that the mean juvenile abundance calculated per female was lowest in the SHbirch and SHpine may indicate that mite assemblages in monoculture stands growing on the spoil heap are less stable compared to monoculture stands growing on forest areas and mixed stands growing on the spoil heap.

Our study indicated the general tendency in colonization of litterbags by mesostigmatid mites. The abundance calculated per $100 \mathrm{~g}$ dry litter mass usually gradually increased during decomposition-it had lower values at the beginning and higher values at the last collection dates of the experiment. This tendency was particularly strong for juvenile gamasid mites in which the lowest abundances were always recorded at the first collection date, 95 days since the experiment started (except for FHpine). Moreover, taking into account habitat type, the percentage litter mass loss significantly affected female and male mites, but not juvenile stages. Resources are utilized during ongoing decomposition (Horodecki et al. 2019), therefore, there is more food for soil decomposers, and consequently, also for soil mite predators such as Mesostigmata (Koehler 1999; Beaulieu and Weeks 2007; Wissuwa et al. 2012; Hasegawa et al. 2013). Our results, therefore, may also indicate that the introduced litter has the strongest impacts on soil gamasid mites at the end part of ongoing decomposition.

\section{Impact of litter type on gamasid instars}

It is still difficult to show that a specific mite species is associated with a given tree species, or has greater preference for a given litter or microhabitat (Maraun and Scheu 2000), although Skorupski (2010) showed differences in the species composition of soil Mesostigmata mites in a common-garden experiment of 14 tree species. Moreover, litter and decomposition can significantly influence and shape the mite assemblages (Urbanowski et al. 2018, 2021; Kamczyc et al. 2019), which is consistent with our results. Also, Osler et al. (2004) recorded a significant relationship between decomposition and soil fauna, but only after $20 \%$ of litter mass loss. As shown by Frouz (2018), communities can also be shaped by the internal structure of assemblages and other soil fauna communities. Furthermore, the structure of leaves is also important. This was strongly stated by Schmidt (2014), who showed that the structure of leaves can significantly affect mite assemblages. However, we recorded insignificant influences of litter type on adult gamasid developmental stages examined, which may suggest that litter type in litterbags is less important for soil gamasid mites than the surrounding environment.

Many studies indicated the negative impact of $P$. serotina on the environment, including its biodiversity (Robakowski et al. 2018; Dyderski and Jagodziński 2019). In Europe, it is an invasive tree species (Dyderski and Jagodziński 2019), which is characterized by relatively fast litter decomposition (Horodecki et al. 2019). Owing to this, it can change not only litter $\mathrm{pH}$ (von Wendorff 1952) but also affect the amount of micro- and 
macro-elements in the topsoil (Lorenz et al. 2004). Interestingly, we recorded high mean abundance of juvenile mites in $P$. serotina litter, therefore, our results may confirm the positive influence on younger developmental stages, but not on adult mites forming soil gamasid communities.

We found that soil mean temperature had a significant effect on male and juvenile mites, but not on gamasid females. This result is consistent with results of Huhta and Hänninen (2001), who showed that some mite species from the Mesostigmata order were significantly dependent on the prevailing ambient temperature. Also, the results of Thakur et al. (2018), indicated that the mites were dependent on environmental conditions such as temperature or humidity. As juvenile mites are less sclerotized than females (Giljarov and Bregetova 1977; Madej 2002; Skubała 2002b), they may be more susceptible to changes in temperature and humidity of the environment. However, some studies confirmed that food availability is more important for mites than appropriate environmental conditions (Fujii and Takeda 2017). Mite males of some gamasid species appear in low numbers, and their presence is seasonal and sporadic, unlike gamasid females (Norton et al. 1993; Błoszyk et al. 2004; Napierała and Błoszyk 2013). This is related to the reproductive strategy of mesostigmatid mite species, among which there is not only sexual, but also parthenogenetic reproduction (Błoszyk et al. 2004). The insignificant influence of soil mean temperature on females recorded in our experiment, may be related to their year-round occurrence, in contrast to male mites, as well as to the reproductive strategy of a given gamasid species that creates soil mite communities.

\section{Conclusions}

We found a significant influence of habitat type on gamasid mite assemblages of females, males and juvenile mites. Additionally, soil mean temperature had a significant effect on male and juvenile mites, but not on gamasid females. Moreover, litter type had a significant influence on mean juvenile abundance, whereas percentage litter mass loss significantly affected the female and juvenile developmental stages. However, taking habitat type into account, the percentage litter mass loss significantly affected female and male mites, but not the juvenile stages. Mite communities (female, male and juvenile instars) colonized litter extensively as decomposition progressed. The abundance calculated per $100 \mathrm{~g}$ dry litter mass usually increased gradually during decomposition-it had lower values at the beginning and the highest values at the last collection dates. The highest mean female, male and juvenile abundances were recorded in birch stands growing on the forest area; however, juvenile mites were also highly numerous in mixed stands on the spoil heap. All of the mesostigmatid developmental stages studied were the least abundant in monoculture stands of Scots pine growing on the spoil heap in comparison to other habitat types studied. We also found that male and juvenile mean abundances were highest in P. tremula litter, whereas females were highest in $U$. laevis. Furthermore, the lowest mean female and male abundances were recorded in $Q$. robur litter, whereas juvenile mites were lowest in $F$. sylvatica litter.

Our results confirm that mixed stands on post-mining areas are a potentially better habitat for mesostigmatid community development compared to monocultures, among others by relatively higher humidity and lower temperatures. Taking into account that the number of juvenile instars ensures the stability of a population and its possible development, it is important to properly shape and revitalize the degraded environment in order to improve the living conditions for Mesostigmata mite populations. 


\section{Appendix 1: Checklist of gamasid species recorded from litterbags on 11 research plots within habitat types}

\begin{tabular}{|c|c|c|c|c|c|c|c|c|c|c|c|c|}
\hline \multirow[t]{3}{*}{ No. } & \multirow[t]{3}{*}{ Mite species } & \multicolumn{11}{|c|}{ Habitat type } \\
\hline & & \multicolumn{2}{|c|}{ FHbirch } & \multicolumn{2}{|c|}{ FHpine } & \multicolumn{3}{|c|}{ SHmixed } & \multicolumn{2}{|c|}{ SHbirch } & \multicolumn{2}{|c|}{ SHpine } \\
\hline & & 1 & 2 & 3 & 4 & 5 & 6 & 7 & 8 & 9 & 10 & 11 \\
\hline 1 & $\begin{array}{l}\text { Trachytes aegrota } \\
\text { (C. L. Koch, } \\
\text { 1841) }\end{array}$ & +++ & +++ & + & ++ & +++ & +++ & +++ & & & + & + \\
\hline 2 & $\begin{array}{l}\text { Veigaia nemoren- } \\
\text { sis (C. L. Koch, } \\
\text { 1839) }\end{array}$ & +++ & +++ & ++ & ++ & +++ & +++ & +++ & & & + & \\
\hline 3 & $\begin{array}{l}\text { Zercon peltatus C. } \\
\text { L. Koch, } 1836\end{array}$ & +++ & +++ & +++ & +++ & + & & & + & + & + & + \\
\hline 4 & $\begin{array}{l}\text { Olodiscus minima } \\
\text { (Kramer, 1882) }\end{array}$ & ++ & +++ & & & +++ & +++ & ++ & & + & + & + \\
\hline 5 & $\begin{array}{l}\text { Gamasellodes } \\
\text { bicolor (Berlsese, } \\
\text { 1918) }\end{array}$ & + & & + & + & +++ & +++ & +++ & & & & \\
\hline 6 & $\begin{array}{l}\text { Paragamasus run- } \\
\text { catellus (Berlese, } \\
1903 \text { sensu Karg, } \\
\text { 1971) }\end{array}$ & ++ & ++ & + & ++ & +++ & +++ & +++ & + & + & + & \\
\hline 7 & $\begin{array}{l}\text { Amblyseius tubae } \\
\text { Karg, } 1970\end{array}$ & ++ & ++ & + & + & & & & +++ & +++ & ++ & ++ \\
\hline 8 & $\begin{array}{l}\text { Veigaia cerva } \\
\quad \text { (Kramer, 1876) }\end{array}$ & ++ & ++ & ++ & ++ & +++ & +++ & ++ & ++ & + & & \\
\hline 9 & Paragamasus sp. & + & ++ & ++ & ++ & +++ & +++ & ++ & + & + & + & \\
\hline 10 & Pergamasus sp. & ++ & ++ & ++ & ++ & +++ & +++ & ++ & + & ++ & ++ & ++ \\
\hline 11 & $\begin{array}{l}\text { Pergamasus cras- } \\
\text { sipes (Linnaeus, } \\
1758 \text { ) }\end{array}$ & + & + & + & + & +++ & +++ & +++ & ++ & + & ++ & ++ \\
\hline 12 & $\begin{array}{l}\text { Vulgarogamasus } \\
\text { kraepelini (Ber- } \\
\text { lese, 1904) }\end{array}$ & + & & & & +++ & +++ & ++ & & & & \\
\hline 13 & Amblyseius sp. & & & + & + & ++ & ++ & +++ & ++ & ++ & + & + \\
\hline 14 & $\begin{array}{l}\text { Asca aphidioides } \\
\quad \text { (Linnaeus, 1758) }\end{array}$ & ++ & ++ & ++ & ++ & ++ & & + & ++ & ++ & ++ & ++ \\
\hline 15 & $\begin{array}{l}\text { Paragamasus conus } \\
\quad \text { (Karg, 1971) }\end{array}$ & + & + & + & + & +++ & +++ & + & + & + & & \\
\hline 16 & $\begin{array}{l}\text { Prozercon trae- } \\
\text { gardhi (Halbert, } \\
\text { 1923) }\end{array}$ & & + & & & ++ & ++ & + & & & & \\
\hline 17 & $\begin{array}{l}\text { Asca bicornis (Can- } \\
\text { estrini \& Fanzago, } \\
\text { 1887) }\end{array}$ & & + & & & + & + & + & ++ & ++ & ++ & ++ \\
\hline 18 & $\begin{array}{l}\text { Pergamasus septen- } \\
\text { trionalis (Oude- } \\
\text { mans, 1902) }\end{array}$ & ++ & ++ & & & ++ & ++ & ++ & + & + & & \\
\hline
\end{tabular}


No. Mite species Habitat type

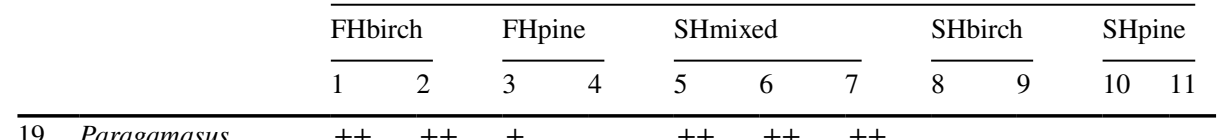

\begin{tabular}{lllllllllllll}
\hline 19 & Paragamasus & ++ & ++ & + & & & ++ & ++ & ++
\end{tabular} jugincola AthiasHenriot, 1967

20 Veigaia kochi (Trägårdh, 1901)

21 Leptogamasus $\quad+\quad+\quad++\quad++$ parvulus (Berlese, 1903)

22 Dendrolaelaps cornutus sensu lato (Kramer, 1886)

23 Veigaia exigua (Berlsese, 1916)

24 Discourella modesta (Leonardi, 1889)

25 Arctoseius insularis (Willmann, 1952)

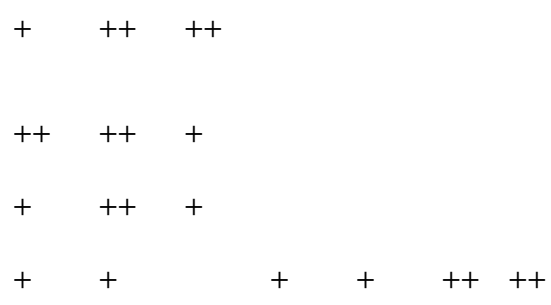

26 Veigaia planicola ++ (Berlese, 1892)

27 Oodinychus ovalis $+\quad+\quad+\quad+\quad+\quad++\quad+$ (C. L. Koch,
1839)

28 Prozercon kochi Sellnick, 1943

29 Iphidozercon gibbus $+\quad++$ Berlese, 1903

30 Hypoaspis aculeifer (Canestrini, 1883)

31 Arctoseius semiscissus (Berlese, 1892)

32 Parazercon radiatus (Berlese, 1914)

33 Hypoaspis praesternalis Willmann, 1949

34 Hypoaspis vacua (Michael, 1891)

35 Epicriopsis horridus $+\quad++$ Kramer, 1876

36 Macrocheles montanus (Willmann, 1951)

37 Dendrolaelaps angulosus (Willmann, 1936)

38 Dendrolaelaps $++$

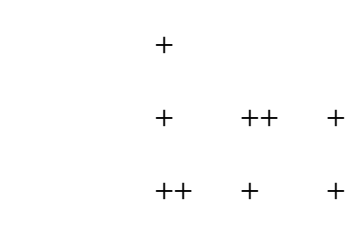
foveolatus (Leitner, 1949) 
No. Mite species

Habitat type

\begin{tabular}{|c|c|c|c|c|c|c|c|c|}
\hline FHbirch & \multicolumn{2}{|c|}{ FHpine } & \multicolumn{3}{|c|}{ SHmixed } & \multicolumn{2}{|c|}{ SHbirch } & SHpine \\
\hline 2 & 3 & 4 & 5 & 6 & 7 & 8 & 9 & 10 \\
\hline
\end{tabular}

39 Geholaspis longispinosus (Kramer, 1876)

40 Dendrolaelaps punctatosimilis Hirschmann, 1960

41 Eulaelaps stabularis (C. L. Koch, 1839)

42 Eviphis ostrinus (C. + L. Koch, 1836)

43 Leptogamasus belligerens Witaliński, 1973

44 Pergamasus barbarus (Berlese, 1904)

45 Pergamasus brevicornis (Berlese, 1903)

46 Dendrolaelaps rotundus Hirschmann, 1960

47 Lasioseius muricatus (C. L. Koch, 1839)

48 Pergamasus mediocris Berlese, 1904

49 Veigaia decurtata Athias-Henriot, 1961

$50 \quad$ Laelaspis astronomicus (C. L. Koch, 1839)

51 Alliphis halleri (Canestrini \& Canestrini, 1881)

52 Ameroseius corbiculus (Sowerby, 1806)

53 Ameroseius pseudoplumosus (Rack, 1972)

54 Antennoseius bacatus AthiasHenriot, 1961

55 Antennoseius masoviae Sellnick, 1943 


\begin{tabular}{|c|c|c|c|c|c|c|c|c|c|c|c|c|}
\hline \multirow[t]{3}{*}{ No. } & \multirow[t]{3}{*}{ Mite species } & \multicolumn{11}{|c|}{ Habitat type } \\
\hline & & \multicolumn{2}{|c|}{ FHbirch } & \multicolumn{2}{|c|}{ FHpine } & \multicolumn{3}{|c|}{ SHmixed } & \multicolumn{2}{|c|}{ SHbirch } & \multicolumn{2}{|c|}{ SHpine } \\
\hline & & 1 & 2 & 3 & 4 & 5 & 6 & 7 & 8 & 9 & 10 & 11 \\
\hline 56 & $\begin{array}{l}\text { Dendrolaelaps } \\
\text { latior (Leitner, } \\
\text { 1949) }\end{array}$ & + & & & & & & & + & & & \\
\hline 57 & $\begin{array}{l}\text { Lasioseius ometes } \\
\quad \text { (Oudemans, 1903) }\end{array}$ & & & & & & + & + & & & & \\
\hline 58 & $\begin{array}{l}\text { Leioseius elongatus } \\
\text { Evans, } 1958\end{array}$ & + & & & & & + & & & & & \\
\hline 59 & $\begin{array}{l}\text { Leptogamasus } \\
\text { suecicus } \\
\text { (Trägårdh, 1936) }\end{array}$ & & & & & & + & & & & & \\
\hline 60 & $\begin{array}{l}\text { Proctolaelaps fisieri } \\
\text { Samšiňák, } 1960\end{array}$ & & & & & + & & & & & & \\
\hline 61 & Ameroseius sp. & & & & & & & + & & & & \\
\hline 62 & $\begin{array}{l}\text { Arctoseius brevi- } \\
\text { chelis Karg, } 1969\end{array}$ & & & & & & & & & + & & \\
\hline 63 & $\begin{array}{l}\text { Arctoseius venus- } \\
\text { tulus (Berlese, } \\
\text { 1917) }\end{array}$ & & & & & & + & & & & & \\
\hline 64 & $\begin{array}{l}\text { Cheiroseius borealis } \\
\text { (Berlese, 1904) }\end{array}$ & & & & & & & & & + & & \\
\hline 65 & $\begin{array}{l}\text { Dendrolaelaps } \\
\text { arvicolus (Leitner, } \\
\text { 1949) }\end{array}$ & & & & & & & + & & & & \\
\hline 66 & $\begin{array}{l}\text { Dendrolaelaps } \\
\text { laetus Shcherbak, } \\
1980\end{array}$ & & + & & & & & & & & & \\
\hline 67 & $\begin{array}{l}\text { Dendrolaelaps } \\
\text { schauenburgi } \\
\text { (Schweizer, 1961) }\end{array}$ & & & & & + & & & & & & \\
\hline 68 & $\begin{array}{l}\text { Dermanyssus gal- } \\
\text { linae (De Geer, } \\
\text { 1778) }\end{array}$ & & & & & & + & & & & & \\
\hline 69 & $\begin{array}{l}\text { Dinychus perforatus } \\
\text { Kramer, } 1882\end{array}$ & & + & & & & & & & & & \\
\hline 70 & $\begin{array}{l}\text { Urobovella pul- } \\
\text { chella (Berlese, } \\
\text { 1904) }\end{array}$ & & + & & & & & & & & & \\
\hline 71 & $\begin{array}{l}\text { Lasioseius confusus } \\
\text { Evans, } 1958\end{array}$ & & & + & & & & & & & & \\
\hline 72 & $\begin{array}{l}\text { Lasioseius formosus } \\
\text { Westerboer, } 1963\end{array}$ & & & & & + & & & & & & \\
\hline 73 & $\begin{array}{l}\text { Leptogamasus } \\
\text { anoxygenenellus } \\
\text { (Micherdziński, } \\
\text { 1969) }\end{array}$ & & & & + & & & & & & & \\
\hline 74 & $\begin{array}{l}\text { Nejordensia levis } \\
\text { (Oudemans et } \\
\text { Voigts, 1904) }\end{array}$ & & & & & & & & & + & & \\
\hline
\end{tabular}




\begin{tabular}{|c|c|c|c|c|c|c|c|c|c|c|c|c|}
\hline \multirow[t]{3}{*}{ No. } & \multirow[t]{3}{*}{ Mite species } & \multicolumn{11}{|c|}{ Habitat type } \\
\hline & & \multicolumn{2}{|c|}{ FHbirch } & \multicolumn{2}{|c|}{ FHpine } & \multicolumn{3}{|c|}{ SHmixed } & \multicolumn{2}{|c|}{ SHbirch } & \multicolumn{2}{|c|}{ SHpine } \\
\hline & & 1 & 2 & 3 & 4 & 5 & 6 & 7 & 8 & 9 & 10 & 11 \\
\hline$\overline{75}$ & $\begin{array}{c}\text { Olodiscus misella } \\
\text { (Berlese, 1916) }\end{array}$ & & & & & & + & & & & & \\
\hline 76 & $\begin{array}{l}\text { Rhodacarellus sile- } \\
\quad \text { siacus Willmann, } \\
1936\end{array}$ & & & & & & & + & & & & \\
\hline 77 & $\begin{array}{l}\text { Sejus togatus C. L. } \\
\text { Koch, } 1836\end{array}$ & & & + & & & & & & & & \\
\hline 78 & $\begin{array}{l}\text { Typhlodromus pyri } \\
\text { Scheuten, } 1857\end{array}$ & & & & + & & & & & & & \\
\hline 79 & $\begin{array}{l}\text { Urodiaspis tecta } \\
\quad \text { (Kramer, 1876) }\end{array}$ & & & & & + & & & & & & \\
\hline 80 & $\begin{array}{l}\text { Veigaia propinqua } \\
\text { Willmann, } 1956\end{array}$ & & & & & & + & & & & & \\
\hline 81 & $\begin{array}{l}\text { Zerconopsis } \\
\text { muestairi (Sch- } \\
\text { weizer, 1949) }\end{array}$ & & & & & & & & & & & + \\
\hline
\end{tabular}

Symbols indicate abundance:,$+ 1-9$ individuals; $++10-99 ;+++>100$. Mite species are ordered by total dominance

FHbirch monoculture stands of silver birch growing on forest habitat, FHpine monoculture stands of Scots pine growing on forest habitat, SHmixed mixed stands growing on spoil heap, SHbirch monoculture stands of silver birch growing on spoil heap, SHpine monoculture stands of Scots pine growing on spoil heap

\section{Appendix 2: Mean $( \pm S D)$ female, male and juvenile abundances per $\mathbf{1 0 0} \mathrm{g}$ dry litter mass within habitat types recorded for each collection date (interval day) since the start of the experiment}

\begin{tabular}{lllll}
\hline Habitat type & Interval day & Female & Male & Juvenile \\
\hline FHbirch & 91 & $45.09 \pm 1.23$ & $143.33 \pm 26.01$ & $55.21 \pm 6.71$ \\
& 182 & $167.92 \pm 95.51$ & $12.24 \pm 9.44$ & $164.67 \pm 73.97$ \\
& 275 & $683.73 \pm 188.87$ & $19.12 \pm 14.41$ & $319.26 \pm 70.27$ \\
& 366 & $1121.28 \pm 294.63$ & $129.52 \pm 58.79$ & $374.03 \pm 61.28$ \\
& 548 & $348.96 \pm 36.95$ & $34.98 \pm 16.33$ & $367.94 \pm 202.19$ \\
& 730 & $581.30 \pm 3.93$ & $227.06 \pm 123.42$ & $273.7 \pm 14.85$ \\
& 913 & $247.96 \pm 201.16$ & $16.97 \pm 15.05$ & $147.40 \pm 150.18$ \\
& 1100 & $1204.44 \pm 416.25$ & $140.30 \pm 52.85$ & $721.93 \pm 94.02$ \\
\hline
\end{tabular}




\begin{tabular}{|c|c|c|c|c|}
\hline Habitat type & Interval day & Female & Male & Juvenile \\
\hline \multirow[t]{8}{*}{ FHpine } & 91 & 0 & 0 & $1.52 \pm 2.15$ \\
\hline & 182 & $63.31 \pm 89.53$ & $4.04 \pm 5.71$ & $5.82 \pm 8.23$ \\
\hline & 275 & $446.40 \pm 16.51$ & $8.49 \pm 0.26$ & $70.37 \pm 38.37$ \\
\hline & 366 & $64.73 \pm 2.76$ & $33.86 \pm 10.03$ & $205.62 \pm 15.75$ \\
\hline & 548 & $186.35 \pm 42.88$ & $46.22 \pm 6.44$ & $98.05 \pm 8.80$ \\
\hline & 730 & $191.03 \pm 135.14$ & $58.70 \pm 51.50$ & $189.98 \pm 15.30$ \\
\hline & 913 & $3.62 \pm 2.64$ & 0 & $0.82 \pm 1.16$ \\
\hline & 1100 & $133.33 \pm 52.75$ & $33.96 \pm 33.25$ & $213.1 \pm 25.72$ \\
\hline \multirow[t]{10}{*}{ SHmixed } & 95 & $19.16 \pm 15.34$ & $1.67 \pm 2.90$ & $2.68 \pm 2.32$ \\
\hline & 196 & $153.65 \pm 106.03$ & $13.38 \pm 8.59$ & $248.02 \pm 205.74$ \\
\hline & 285 & $224.72 \pm 115.89$ & $15.90 \pm 6.06$ & $248.50 \pm 183.09$ \\
\hline & 385 & $148.10 \pm 40.98$ & $7.07 \pm 2.54$ & $53.34 \pm 45.61$ \\
\hline & 564 & $175.88 \pm 136.55$ & $15.87 \pm 10.68$ & $508.52 \pm 508.83$ \\
\hline & 753 & $208.82 \pm 177.90$ & $16.22 \pm 9.97$ & $117.59 \pm 144.38$ \\
\hline & 936 & $187.92 \pm 90.02$ & $4.96 \pm 4.63$ & $574.36 \pm 422.52$ \\
\hline & 1117 & $155.79 \pm 58.25$ & $22.73 \pm 10.23$ & $147.33 \pm 157.16$ \\
\hline & 1298 & $162.14 \pm 98.56$ & $19.42 \pm 9.30$ & $121.63 \pm 86.84$ \\
\hline & 1754 & $740.41 \pm 471.20$ & $44.70 \pm 30.13$ & $106.32 \pm 42.83$ \\
\hline \multirow[t]{8}{*}{ SHbirch } & 91 & 0 & 0 & $0.65 \pm 0.93$ \\
\hline & 182 & 0 & 0 & 0 \\
\hline & 275 & $307.10 \pm 32.01$ & $53.20 \pm 27.97$ & $43.55 \pm 16.81$ \\
\hline & 366 & $152.92 \pm 40.79$ & $8.59 \pm 5.74$ & $3.69 \pm 0.90$ \\
\hline & 548 & $10.93 \pm 4.92$ & $11.44 \pm 6.80$ & $3.22 \pm 2.41$ \\
\hline & 730 & $317.28 \pm 309.24$ & $4.22 \pm 1.04$ & $2.75 \pm 1.44$ \\
\hline & 913 & $6.05 \pm 8.55$ & $5.35 \pm 1.14$ & $6.16 \pm 8.71$ \\
\hline & 1100 & $162.43 \pm 66.69$ & $1.16 \pm 1.64$ & $5.76 \pm 3.27$ \\
\hline \multirow[t]{8}{*}{ SHpine } & 91 & $0.79 \pm 1.11$ & 0 & $0.75 \pm 1.06$ \\
\hline & 182 & 0 & 0 & 0 \\
\hline & 275 & $70.30 \pm 10.84$ & $21.88 \pm 1.19$ & $40.02 \pm 15.25$ \\
\hline & 366 & $34.06 \pm 22.45$ & $7.44 \pm 3.88$ & $2.81 \pm 3.98$ \\
\hline & 548 & $18.22 \pm 14.57$ & $3.81 \pm 3.78$ & $4.62 \pm 2.27$ \\
\hline & 730 & $45.74 \pm 15.56$ & $4.64 \pm 6.57$ & $1.03 \pm 1.45$ \\
\hline & 913 & $3.65 \pm 5.16$ & $1.22 \pm 1.72$ & $1.22 \pm 1.72$ \\
\hline & 1100 & $20.02 \pm 9.82$ & $12.74 \pm 5.06$ & $14.61 \pm 15.83$ \\
\hline
\end{tabular}

FHbirch monoculture stands of silver birch growing on forest habitat, FHpine monoculture stands of Scots pine growing on forest habitat, SHmixed mixed stands growing on spoil heap, SHbirch monoculture stands of silver birch growing on spoil heap, SHpine monoculture stands of Scots pine growing on spoil heap 
Appendix 3: Mean $( \pm$ SD) female, male and juvenile abundances per $100 \mathrm{~g}$ dry litter mass within 14 litter types recorded for each collection date (interval day) since the start of the experiment

\begin{tabular}{|c|c|c|c|c|}
\hline Litter type & Interval day & Female & Male & Juvenile \\
\hline \multirow[t]{10}{*}{ Ace_pse } & 95 & $21.97 \pm 18.25$ & $1.25 \pm 2.17$ & $6.04 \pm 7.50$ \\
\hline & 196 & $445.68 \pm 223.06$ & $64.77 \pm 71.64$ & $421.52 \pm 383.11$ \\
\hline & 285 & $303.04 \pm 91.14$ & $8.80 \pm 5.73$ & $348.99 \pm 224.22$ \\
\hline & 385 & $256.16 \pm 179.81$ & $15.24 \pm 19.70$ & $108.64 \pm 145.65$ \\
\hline & 564 & $264.30 \pm 293.83$ & $69.75 \pm 41.75$ & $638.70 \pm 592.07$ \\
\hline & 753 & $293.86 \pm 176.27$ & $24.79 \pm 16.66$ & $385.72 \pm 475.08$ \\
\hline & 936 & $241.22 \pm 132.22$ & $17.86 \pm 30.94$ & $436.03 \pm 163.21$ \\
\hline & 1117 & $244.84 \pm 314.89$ & $77.70 \pm 134.58$ & $745.74 \pm 1291.66$ \\
\hline & 1298 & $343.34 \pm 122.61$ & $26.65 \pm 46.15$ & $268.26 \pm 140.57$ \\
\hline & 1754 & $645.52 \pm 478.74$ & 0 & $189.10 \pm 183.53$ \\
\hline \multirow[t]{10}{*}{ Aln_glu } & 95 & $24.84 \pm 21.92$ & $1.88 \pm 3.25$ & $3.67 \pm 4.20$ \\
\hline & 196 & $281.85 \pm 249.64$ & $11.36 \pm 10.44$ & $542.98 \pm 473.00$ \\
\hline & 285 & $254.83 \pm 135.75$ & $20.31 \pm 17.81$ & $379.65 \pm 312.31$ \\
\hline & 385 & $195.77 \pm 57.90$ & $10.61 \pm 4.14$ & $106.26 \pm 99.04$ \\
\hline & 564 & $236.19 \pm 238.20$ & $24.24 \pm 23.32$ & $861.82 \pm 1167.16$ \\
\hline & 753 & $264.23 \pm 376.36$ & $10.53 \pm 9.44$ & $57.29 \pm 99.24$ \\
\hline & 936 & $94.24 \pm 82.64$ & 0 & $968.95 \pm 816.75$ \\
\hline & 1117 & $52.88 \pm 45.82$ & 0 & $46.03 \pm 79.72$ \\
\hline & 1298 & $118.10 \pm 50.66$ & 0 & $69.73 \pm 33.98$ \\
\hline & 1754 & $1030.30 \pm 424.53$ & $114.60 \pm 105.92$ & $105.37 \pm 42.57$ \\
\hline \multirow[t]{10}{*}{ Bet_pen } & 95 & $23.25 \pm 9.67$ & $2.46 \pm 4.27$ & $1.21 \pm 2.09$ \\
\hline & 196 & $70.45 \pm 42.84$ & $11.09 \pm 8.98$ & $84.54 \pm 72.65$ \\
\hline & 285 & $266.85 \pm 173.28$ & $17.32 \pm 8.12$ & $210.64 \pm 117.71$ \\
\hline & 385 & $118.32 \pm 34.42$ & $11.91 \pm 5.05$ & $7.81 \pm 6.86$ \\
\hline & 564 & $135.62 \pm 97.91$ & $16.29 \pm 15.39$ & $367.53 \pm 305.70$ \\
\hline & 753 & $208.31 \pm 23.50$ & $20.36 \pm 18.59$ & $136.33 \pm 110.04$ \\
\hline & 936 & $366.70 \pm 245.34$ & $12.50 \pm 11.06$ & $613.13 \pm 773.04$ \\
\hline & 1117 & $326.72 \pm 137.94$ & $74.20 \pm 33.81$ & $238.85 \pm 237.89$ \\
\hline & 1298 & $141.09 \pm 176.73$ & $30.63 \pm 29.09$ & $111.69 \pm 96.76$ \\
\hline & 1754 & $1119.86 \pm 1635.19$ & $4.73 \pm 8.20$ & $47.15 \pm 34.79$ \\
\hline \multirow[t]{10}{*}{ Fag_syl } & 95 & $17.43 \pm 12.68$ & $3.50 \pm 6.06$ & $3.48 \pm 3.52$ \\
\hline & 196 & $140.42 \pm 47.49$ & $28.25 \pm 15.94$ & $134.20 \pm 99.00$ \\
\hline & 285 & $181.52 \pm 41.18$ & $38.97 \pm 22.28$ & $133.73 \pm 109.80$ \\
\hline & 385 & $154.65 \pm 90.49$ & $10.60 \pm 12.29$ & $24.69 \pm 13.81$ \\
\hline & 564 & $54.63 \pm 51.25$ & $27.83 \pm 48.21$ & $92.76 \pm 87.77$ \\
\hline & 753 & $87.50 \pm 75.94$ & $7.10 \pm 8.82$ & $16.73 \pm 21.55$ \\
\hline & 936 & $90.73 \pm 85.86$ & $7.69 \pm 3.04$ & $197.40 \pm 182.57$ \\
\hline & 1117 & $100.27 \pm 20.59$ & $1.71 \pm 2.96$ & $84.78 \pm 72.71$ \\
\hline & 1298 & $212.02 \pm 192.33$ & $25.10 \pm 19.10$ & $193.84 \pm 171.94$ \\
\hline & 1754 & $162.34 \pm 110.46$ & $15.39 \pm 26.65$ & $104.47 \pm 40.32$ \\
\hline
\end{tabular}




\begin{tabular}{|c|c|c|c|c|}
\hline Litter type & Interval day & Female & Male & Juvenile \\
\hline \multirow[t]{10}{*}{ Fra_exc } & 95 & $38.61 \pm 44.96$ & $6.55 \pm 5.89$ & $6.59 \pm 5.92$ \\
\hline & 196 & $182.59 \pm 84.79$ & $14.39 \pm 8.25$ & $173.80 \pm 137.39$ \\
\hline & 285 & $392.44 \pm 303.38$ & $40.41 \pm 14.44$ & $559.46 \pm 466.35$ \\
\hline & 385 & $281.31 \pm 160.82$ & $15.29 \pm 26.48$ & $41.39 \pm 42.63$ \\
\hline & 564 & $157.61 \pm 160.55$ & $17.16 \pm 15.13$ & $511.10 \pm 652.67$ \\
\hline & 753 & $486.05 \pm 205.55$ & $23.46 \pm 22.66$ & $343.12 \pm 345.43$ \\
\hline & 936 & $279.20 \pm 310.16$ & $12.73 \pm 22.05$ & $931.80 \pm 1046.66$ \\
\hline & 1117 & $209.96 \pm 184.37$ & 0 & $73.33 \pm 115.26$ \\
\hline & 1298 & $388.20 \pm 20.99$ & $74.80 \pm 74.44$ & $167.55 \pm 128.70$ \\
\hline & 1754 & $592.11 \pm 136.74$ & 0 & $196.53 \pm 126.75$ \\
\hline \multirow[t]{10}{*}{ Pin_syl } & 95 & $9.76 \pm 6.63$ & $1.76 \pm 3.05$ & $3.57 \pm 3.10$ \\
\hline & 196 & $139.37 \pm 81.58$ & $17.12 \pm 13.17$ & $168.66 \pm 169.00$ \\
\hline & 285 & $163.83 \pm 93.51$ & $12.98 \pm 7.49$ & $204.09 \pm 235.06$ \\
\hline & 385 & $132.01 \pm 79.98$ & 0 & $54.99 \pm 44.57$ \\
\hline & 564 & $201.38 \pm 193.61$ & $9.36 \pm 4.81$ & $357.20 \pm 319.09$ \\
\hline & 753 & $215.83 \pm 141.35$ & $25.52 \pm 22.98$ & $178.27 \pm 218.80$ \\
\hline & 936 & $174.75 \pm 48.98$ & $3.69 \pm 6.40$ & $356.84 \pm 245.18$ \\
\hline & 1117 & $98.87 \pm 41.45$ & $1.73 \pm 3.00$ & $173.39 \pm 233.17$ \\
\hline & 1298 & $231.81 \pm 92.09$ & $18.34 \pm 10.91$ & $165.04 \pm 115.87$ \\
\hline & 1754 & $291.84 \pm 139.28$ & $34.80 \pm 29.72$ & $135.08 \pm 58.67$ \\
\hline \multirow[t]{10}{*}{ Pop_can } & 95 & $58.81 \pm 14.21$ & $9.27 \pm 3.09$ & $8.20 \pm 4.77$ \\
\hline & 196 & $187.08 \pm 167.86$ & $12.63 \pm 11.39$ & $192.28 \pm 141.01$ \\
\hline & 285 & $245.37 \pm 217.23$ & $11.53 \pm 13.12$ & $241.39 \pm 154.13$ \\
\hline & 385 & $174.27 \pm 21.18$ & $5.24 \pm 5.71$ & $74.36 \pm 89.78$ \\
\hline & 564 & $149.83 \pm 139.82$ & $17.31 \pm 14.04$ & $403.89 \pm 578.32$ \\
\hline & 753 & $246.33 \pm 50.54$ & $15.83 \pm 27.42$ & $165.75 \pm 141.76$ \\
\hline & 936 & $14.11 \pm 6.31$ & 0 & $72.77 \pm 72.94$ \\
\hline & 1117 & $405.62 \pm 552.54$ & $93.70 \pm 162.30$ & $772.28 \pm 1337.63$ \\
\hline & 1298 & $211.01 \pm 114.05$ & 0 & $261.96 \pm 317.30$ \\
\hline & 1754 & $1755.84 \pm 1995.99$ & $23.11 \pm 24.52$ & $192.59 \pm 108.42$ \\
\hline \multirow[t]{10}{*}{ Pop_nig } & 95 & $19.50 \pm 15.79$ & 0 & $5.38 \pm 5.37$ \\
\hline & 196 & $96.97 \pm 34.46$ & $13.57 \pm 5.10$ & $361.05 \pm 190.78$ \\
\hline & 285 & $222.34 \pm 100.10$ & $20.64 \pm 17.06$ & $181.18 \pm 116.67$ \\
\hline & 385 & $106.02 \pm 35.97$ & $8.37 \pm 7.94$ & $16.81 \pm 21.12$ \\
\hline & 564 & $88.14 \pm 85.25$ & $6.98 \pm 8.02$ & $274.51 \pm 92.30$ \\
\hline & 753 & $127.61 \pm 167.60$ & $9.91 \pm 17.17$ & $97.46 \pm 111.07$ \\
\hline & 936 & $100.80 \pm 79.60$ & $4.84 \pm 4.33$ & $207.88 \pm 290.58$ \\
\hline & 1117 & $159.66 \pm 92.48$ & $2.62 \pm 4.53$ & $52.66 \pm 82.75$ \\
\hline & 1298 & $192.37 \pm 91.78$ & $30.29 \pm 17.26$ & $133.99 \pm 106.34$ \\
\hline & 1754 & $435.25 \pm 236.52$ & $8.17 \pm 7.53$ & $116.38 \pm 59.28$ \\
\hline
\end{tabular}




\begin{tabular}{|c|c|c|c|c|}
\hline Litter type & Interval day & Female & Male & Juvenile \\
\hline \multirow[t]{10}{*}{ Pop_tre } & 95 & $14.38 \pm 7.29$ & $1.16 \pm 2.01$ & $4.70 \pm 5.33$ \\
\hline & 196 & $276.14 \pm 115.48$ & $34.47 \pm 22.75$ & $222.94 \pm 157.86$ \\
\hline & 285 & $384.09 \pm 232.81$ & $13.05 \pm 8.18$ & $232.87 \pm 189.73$ \\
\hline & 385 & $240.57 \pm 125.45$ & $9.51 \pm 8.80$ & $38.39 \pm 11.78$ \\
\hline & 564 & $185.57 \pm 144.54$ & $3.19 \pm 5.53$ & $463.29 \pm 472.36$ \\
\hline & 753 & $277.55 \pm 95.83$ & $12.95 \pm 22.44$ & $49.86 \pm 39.39$ \\
\hline & 936 & $209.92 \pm 221.63$ & $5.73 \pm 9.93$ & $1882.51 \pm 2544.38$ \\
\hline & 1117 & $254.14 \pm 55.07$ & $48.31 \pm 83.67$ & $71.94 \pm 71.68$ \\
\hline & 1298 & $300.84 \pm 340.74$ & $25.08 \pm 22.02$ & $1355.94 \pm 1862.42$ \\
\hline & 1754 & $1054.16 \pm 1185.04$ & $383.14 \pm 663.62$ & $797.58 \pm 1091.77$ \\
\hline \multirow[t]{10}{*}{ Pru_ser } & 95 & $40.10 \pm 39.22$ & 0 & $4.43 \pm 4.75$ \\
\hline & 196 & $181.20 \pm 163.63$ & $23.13 \pm 25.10$ & $145.18 \pm 137.40$ \\
\hline & 285 & $242.23 \pm 236.27$ & $29.27 \pm 42.29$ & $336.28 \pm 347.47$ \\
\hline & 385 & $280.76 \pm 29.43$ & $4.59 \pm 7.95$ & $33.33 \pm 30.95$ \\
\hline & 564 & $480.32 \pm 483.45$ & $7.98 \pm 13.83$ & $1078.41 \pm 1441.01$ \\
\hline & 753 & $510.25 \pm 390.21$ & $73.77 \pm 67.44$ & $460.36 \pm 286.27$ \\
\hline & 936 & 0 & 0 & $437.81 \pm 758.32$ \\
\hline & 1117 & $722.34 \pm 1190.74$ & $165.84 \pm 287.24$ & $2172.53 \pm 3762.94$ \\
\hline & 1298 & $96.15 \pm 83.28$ & 0 & $69.20 \pm 67.52$ \\
\hline & 1754 & $164.51 \pm 158.67$ & $14.15 \pm 24.52$ & $260.50 \pm 68.84$ \\
\hline \multirow[t]{10}{*}{ Que_rob } & 95 & $12.01 \pm 20.80$ & 0 & $1.59 \pm 2.76$ \\
\hline & 196 & $58.13 \pm 29.21$ & $17.02 \pm 12.74$ & $60.35 \pm 52.48$ \\
\hline & 285 & $211.86 \pm 234.45$ & $9.08 \pm 11.40$ & $125.12 \pm 176.07$ \\
\hline & 385 & $122.27 \pm 58.32$ & $7.32 \pm 3.08$ & $9.14 \pm 11.30$ \\
\hline & 564 & $60.84 \pm 50.32$ & $11.42 \pm 10.01$ & $310.55 \pm 309.88$ \\
\hline & 753 & $84.77 \pm 91.02$ & $2.80 \pm 4.86$ & $88.74 \pm 139.39$ \\
\hline & 936 & $44.04 \pm 41.63$ & $2.36 \pm 4.09$ & $142.66 \pm 141.39$ \\
\hline & 1117 & $133.58 \pm 50.40$ & $7.22 \pm 6.26$ & $114.78 \pm 93.68$ \\
\hline & 1298 & $152.96 \pm 128.37$ & $38.03 \pm 35.45$ & $158.52 \pm 148.68$ \\
\hline & 1754 & $298.89 \pm 249.75$ & $4.61 \pm 7.99$ & $169.06 \pm 280.92$ \\
\hline \multirow[t]{10}{*}{ Que_rub } & 95 & $20.58 \pm 9.02$ & 0 & $3.42 \pm 5.93$ \\
\hline & 196 & $206.54 \pm 163.57$ & $20.89 \pm 10.37$ & $168.41 \pm 144.94$ \\
\hline & 285 & $294.59 \pm 254.73$ & $20.96 \pm 9.29$ & $187.38 \pm 171.57$ \\
\hline & 385 & $144.55 \pm 44.89$ & $10.38 \pm 9.18$ & $25.37 \pm 30.51$ \\
\hline & 564 & $128.29 \pm 106.67$ & $13.58 \pm 7.22$ & $163.60 \pm 154.52$ \\
\hline & 753 & $224.31 \pm 228.58$ & 0 & $180.66 \pm 302.47$ \\
\hline & 936 & $130.06 \pm 86.53$ & $2.59 \pm 4.48$ & $213.58 \pm 100.18$ \\
\hline & 1117 & $239.58 \pm 184.76$ & $20.29 \pm 19.31$ & $236.09 \pm 246.51$ \\
\hline & 1298 & $183.62 \pm 151.44$ & $5.06 \pm 8.77$ & $305.40 \pm 129.60$ \\
\hline & 1754 & $351.45 \pm 263.83$ & $25.16 \pm 22.17$ & $51.46 \pm 41.62$ \\
\hline
\end{tabular}




\begin{tabular}{llllc}
\hline Litter type & Interval day & Female & Male & Juvenile \\
\hline Rob_pse & 95 & $37.05 \pm 0.55$ & $6.22 \pm 4.13$ & $8.68 \pm 5.81$ \\
& 196 & $70.23 \pm 17.45$ & $11.65 \pm 7.43$ & $205.66 \pm 154.63$ \\
& 285 & $178.87 \pm 96.61$ & $8.64 \pm 7.49$ & $143.10 \pm 130.49$ \\
& 385 & $143.97 \pm 68.64$ & $15.06 \pm 9.31$ & $10.78 \pm 7.52$ \\
& 564 & $112.61 \pm 97.77$ & $16.08 \pm 18.02$ & $195.10 \pm 211.20$ \\
& 753 & $156.37 \pm 17.53$ & $12.18 \pm 1.60$ & $45.35 \pm 10.77$ \\
& 936 & $135.45 \pm 112.16$ & $13.66 \pm 16.41$ & $175.49 \pm 191.75$ \\
& 1117 & $180.16 \pm 138.03$ & $7.27 \pm 6.31$ & $165.20 \pm 116.85$ \\
& 1298 & $328.56 \pm 208.11$ & $43.10 \pm 21.51$ & $182.37 \pm 114.74$ \\
& 1754 & $262.55 \pm 141.32$ & $61.90 \pm 13.25$ & $110.34 \pm 66.26$ \\
& 95 & $32.94 \pm 15.33$ & $5.48 \pm 1.96$ & $5.29 \pm 1.84$ \\
& 196 & $240.40 \pm 141.99$ & $25.92 \pm 3.88$ & $264.31 \pm 192.76$ \\
& 285 & $217.50 \pm 161.30$ & $11.27 \pm 7.75$ & $317.28 \pm 333.74$ \\
& 385 & $256.98 \pm 218.95$ & $13.71 \pm 12.61$ & $139.88 \pm 150.26$ \\
& 564 & $94.25 \pm 82.15$ & $3.80 \pm 3.34$ & $454.73 \pm 388.49$ \\
& 753 & $782.74 \pm 715.41$ & $43.05 \pm 43.83$ & $510.67 \pm 451.61$ \\
& 936 & $194.11 \pm 336.21$ & $78.05 \pm 85.95$ & $529.06 \pm 730.71$ \\
& 1117 & $359.17 \pm 439.75$ & $15.52 \pm 26.88$ & $37.90 \pm 33.42$ \\
& 1298 & $1700.78 \pm 2140.56$ & 0 & $285.76 \pm 168.39$ \\
& 1754 & $1348.60 \pm 890.47$ & $6.57 \pm 11.37$ & $761.91 \pm 681.43$ \\
\hline
\end{tabular}

Litter types are abbreviated to the first three letters of genera name and first three letters of the species name

Acknowledgements This study was financially supported by the General Directorate of State Forests, Warsaw, Poland (research project 'Environmental and genetic factors affecting productivity of forest ecosystems on forest and post-industrial habitats') and the Institute of Dendrology, Polish Academy of Sciences, Kórnik, Poland. We kindly thank Dr. Lee E. Frelich (The University of Minnesota Center for Forest Ecology, USA) for linguistic support and comments on the early draft of the manuscript.

Open Access This article is licensed under a Creative Commons Attribution 4.0 International License, which permits use, sharing, adaptation, distribution and reproduction in any medium or format, as long as you give appropriate credit to the original author(s) and the source, provide a link to the Creative Commons licence, and indicate if changes were made. The images or other third party material in this article are included in the article's Creative Commons licence, unless indicated otherwise in a credit line to the material. If material is not included in the article's Creative Commons licence and your intended use is not permitted by statutory regulation or exceeds the permitted use, you will need to obtain permission directly from the copyright holder. To view a copy of this licence, visit http://creativecommons.org/licenses/by/4.0/.

\section{References}

Alberti G, di Palma A, Krantz GW, Błaszak C (2010) First ultrastructural observations on a putative sperm access system in veigaiid females (Veigaiidae, Gamasida). In: Sabelis MW, Bruin J (eds) Trends in acarology. Springer, Dordrecht, pp 59-64

Azevedo LH, Ferreira MP, de Castilho RC et al (2018) Potential of Macrocheles species (Acari: Mesostigmata: Macrochelidae) as control agents of harmful flies (Diptera) and biology of Macrocheles embersoni Azevedo, Castilho and Berto on Stomoxys calcitrans (L.) and Musca domestica L. (Diptera: Muscidae). Biol Control 123:1-8. https://doi.org/10.1016/j.biocontrol.2018.04.013

Bates D, Mächler M, Bolker B, Walker S (2015) Fitting linear mixed-effects models using lme4. J Stat Softw 67:1-48. https://doi.org/10.18637/jss.v067.i01 
Beaulieu F, Weeks AR (2007) Free-living mesostigmatic mites in Australia: their roles in biological control and bioindication. Aust J Exp Agric 47:460-478. https://doi.org/10.1071/EA05341

Berg B, McClaugherty C (2014) Plant litter, decomposition, humus formation, carbon sequestration. Springer, Berlin

Błoszyk J, Adamski Z, Napierała A, Dylewska M (2004) Parthenogenesis as a life strategy among mites of the suborder Uropodina (Acari: Mesostigmata). Can J Zool 82:1503-1511. https://doi.org/10.1139/ z04-133

Bogdanowicz W, Chudzicka E, Pilipiuk I, Skibińska E (2008) Fauna of Poland-characteristics and checklist of species. Muzeum i Instytut Zoologii PAN, Warszawa

Brückner A, Klompen H, Bruce AI et al (2017) Infection of army ant pupae by two new parasitoid mites (Mesostigmata: Uropodina). PeerJ 5:e3870. https://doi.org/10.7717/peerj.3870

Cavard X, Macdonald SE, Bergeron Y, Chen HYH (2011) Importance of mixedwoods for biodiversity conservation: evidence for understory plants, songbirds, soil fauna, and ectomycorrhizae in northern forests. Environ Rev 19:142-161. https://doi.org/10.1139/a11-004

Cesarz S, Fahrenholz N, Migge-Kleian S et al (2007) Earthworm communities in relation to tree diversity in a deciduous forest. Eur J Soil Biol 43:S61-S67. https://doi.org/10.1016/j.ejsobi.2007.08.003

Chaturvedi RK, Singh JS (2017) Restoration of mine spoil in a dry tropical region: a review. Proc Indian Natl Sci Acad USA 83:789-844. https://doi.org/10.16943/ptinsa/2017/49123

de Mendiburu F (2013) Statistical procedures for agricultural research. Package 'Agricolae,' version 1.44. Comprehensive R Archive Network, Institute for Statistics and Mathematics, Vienna, Austria

Dyderski MK, Jagodziński AM (2019) Seedling survival of Prunus serotina Ehrh., Quercus rubra L. and Robinia pseudoacacia L. in temperate forests of Western Poland. For Ecol Manag 450:117498. https://doi.org/10.1016/j.foreco.2019.117498

Eisenhauer N, Antunes PM, Bennett AE et al (2017) Priorities for research in soil ecology. Pedobiologia 63:1-7. https://doi.org/10.1016/j.pedobi.2017.05.003

Elmer M, La France M, Förster G, Roth M (2004) Changes in the decomposer community when converting spruce monocultures to mixed spruce/beech stands. Plant Soil 264:97-109. https://doi.org/10. 1023/B:PLSO.0000047776.86805.0f

FAO, Itps, GSBI, Cbd and EC (2020) State of knowledge of soil biodiversity-status, challenges and potentialities: Report 2020. FAO, Rome

Field CB, Behrenfeld MJ, Randerson JT, Falkowski P (1998) Primary production of the biosphere: integrating terrestrial and oceanic components. Science 281:237-240. https://doi.org/10.1126/science. 281.5374 .237

Frouz J (2018) Effects of soil macro- and mesofauna on litter decomposition and soil organic matter stabilization. Geoderma 332:161-172. https://doi.org/10.1016/j.geoderma.2017.08.039

Fujii S, Takeda H (2017) Succession of soil microarthropod communities during the aboveground and belowground litter decomposition processes. Soil Biol Biochem 110:95-102. https://doi.org/10. 1016/j.soilbio.2017.03.003

Giljarov MS, Bregetova NG (1977) A key to soil-inhabiting mites, Mesostigmata. Nauka, Moscow ((in Russian))

Graca MAS, Bärlocher F, Gessner MO (2005) Methods to study litter decomposition. A practical guide. Springer, Dordrecht

Gwiazdowicz DJ (2007) Ascid mites (Acari. Mesostigmata) from selected forest ecosystems and microhabitats in Poland. Akademia Rolnicza im. Augusta Cieszkowskiego, Poznań

Hasegawa M, Okabe K, Fukuyama K et al (2013) Community structures of Mesostigmata, Prostigmata and Oribatida in broad-leaved regeneration forests and conifer plantations of various ages. Exp Appl Acarol 59:391-408. https://doi.org/10.1007/s10493-012-9618-x

Horodecki P, Jagodziński AM (2019) Site type effect on litter decomposition rates: a three-year comparison of decomposition process between spoil heap and forest sites. Forests 10:353. https://doi.org/ 10.3390/f10040353

Horodecki P, Nowiński M, Jagodziński AM (2019) Advantages of mixed tree stands in restoration of upper soil layers on postmining sites: a five-year leaf litter decomposition experiment. Land Degrad Dev 30:3-13. https://doi.org/10.1002/ldr.3194

Huhta V, Hänninen S-M (2001) Effects of temperature and moisture fluctuations on an experimental soil microarthropod community. Pedobiologia 45:279-286. https://doi.org/10.1078/0031-4056-00085

Irmler $\mathrm{U}$ (2000) Changes in the fauna and its contribution to mass loss and $\mathrm{N}$ release during leaf litter decomposition in two deciduous forests. Pedobiologia 44:105-118. https://doi.org/10.1078/S00314056(04)70032-3 
Jagodziński AM, Wierzcholska S, Dyderski MK et al (2018) Tree species effects on bryophyte guilds on a reclaimed post-mining site. Ecol Eng 110:117-127. https://doi.org/10.1016/j.ecoleng.2017.10. 015

Kamczyc J, Dyderski MK, Horodecki P, Jagodziński AM (2019) Mite communities (Acari, Mesostigmata) in the initially decomposed 'litter islands' of 11 tree species in scots pine (Pinus sylvestris L.) forest. Forests 10:403. https://doi.org/10.3390/f10050403

Kampichler C, Bruckner A (2009) The role of microarthropods in terrestrial decomposition: a metaanalysis of 40 years of litterbag studies. Biol Rev 84:375-389. https://doi.org/10.1111/j.1469185X.2009.00078.x

Karg W (1971) Acari (Acarina) Milben, Unterordnung Anactinochaeta (Parasitiformes). Die freilebenden Gamasina (Gamasides). Raubmilben, Die Tierwelt Deutschlands 59. Gustav Fischer Verlag, Jena

Karg W (1993) Acari (Acarina) Milben Parasitiformes (Anactinochaeta), Cohors Gamasina Leach Raubmmilben. Die Tierwelt Deutschlands. VEB Gustav Fischer Verlag, Jena

Koehler HH (1997) Mesostigmata (Gamasina, Uropodina), efficient predators in agroecosystems. Agric Ecosyst Environ 62:105-117. https://doi.org/10.1016/S0167-8809(96)01141-3

Koehler HH (1999) Predatory mites (Gamasina, Mesostigmata). Agric Ecosyst Environ 74:395-410. https:// doi.org/10.1016/S0167-8809(99)00045-6

Korboulewsky N, Perez G, Chauvat M (2016) How tree diversity affects soil fauna diversity: a review. Soil Biol Biochem 94:94-106. https://doi.org/10.1016/j.soilbio.2015.11.024

Kuznetsova A, Brockhoff PB, Christensen RHB (2017) lmerTest Package: tests in linear mixed effects models. J Stat Softw 82:1-26. https://doi.org/10.18637/jss.v082.i13

Lawrence KL, Wise DH (2000) Spider predation on forest-floor Collembola and evidence for indirect effects on decomposition. Pedobiologia 44:33-39. https://doi.org/10.1078/S0031-4056(04)70026-8

Lawrence KL, Wise DH (2004) Unexpected indirect effect of spiders on the rate of litter disappearance in a deciduous forest. Pedobiologia 48:149-157. https://doi.org/10.1016/j.pedobi.2003.11.001

Lorenz K, Preston CM, Krumrei S, Feger K-H (2004) Decomposition of needle/leaf litter from Scots pine, black cherry, common oak and European beech at a conurbation forest site. Eur J for Res 123:177-188. https://doi.org/10.1007/s10342-004-0025-7

Madej G (2002) Roztocze Mesostigmata (Arachnida, Acari) jako dobry wskaźnik stadiów sukcesyjnych hałd [Soil mesostigmatid mites (Arachnida, Acari) as a good indicator of succession stages on dumps]. Kosmos 51:205-211

Madej G (2004) Rozwój zgrupowań roztoczy Mesostigmata (Arachnida. Acari) na nieużytkach poprzemysłowych [Development of communities of mesostigmatid mite (Arachnida, Acari) in areas of postindustrial wastelands]. Uniwersytet Śląski, Katowice

Madej G, Skubała P (1996) Communites of mites (Acari) on old galena-calamine mining wastelands at Galman, Poland. Pedobiologia 40:311-327

Madej G, Skubała P (2002) Colonization of a dolomitic dump by mesostigmatid mites (Acari, Mesostigmata). In: Bernini F, Nannelli R, Nuzzaci G, de Lillo E (eds) Acarid phylogeny and evolution: adaptation in mites and ticks. Springer, Dordrecht

Maraun M, Scheu S (2000) The structure of oribatid mite communities (Acari, Oribatida): patterns, mechanisms and implications for future research. Ecography 23:374-382. https://doi.org/10.1111/j.16000587.2000.tb00294.x

Micherdziński W (1969) Die Familie Parasitidae Oudemans. 1901 (Acarina, Mesostigmata). PWN, Kraków

Miller TEX, Rudolf VHW (2011) Thinking inside the box: community-level consequences of stage-structured populations. Trends Ecol Evol 26:457-466. https://doi.org/10.1016/j.tree.2011.05.005

Mueller KE, Eisenhauer N, Reich PB et al (2016) Light, earthworms, and soil resources as predictors of diversity of 10 soil invertebrate groups across monocultures of 14 tree species. Soil Biol Biochem 92:184-198. https://doi.org/10.1016/j.soilbio.2015.10.010

Murvanidze M, Mumladze L, Arabuli T, Kvavadze E (2013) Oribatid mite colonization of sand and manganese tailing sites. Acarologia 53:203-215. https://doi.org/10.1051/acarologia/20132089

Mwabvu T (2014) Surface-active millipedes (Diplopoda) and associated mites (Acari, Mesostigmata) in Pigeon Valley Nature Reserve in Durban, South Africa. Soil Organisms 86:147-151

Napierała A, Błoszyk J (2013) Unstable microhabitats (merocenoses) as specific habitats of Uropodina mites (Acari: Mesostigmata). Exp Appl Acarol 60:163-180. https://doi.org/10.1007/s10493-013-9659-9

Neuner S, Albrecht A, Cullmann D et al (2015) Survival of Norway spruce remains higher in mixed stands under a dryer and warmer climate. Glob Chang Biol 21:935-946. https://doi.org/10.1111/gcb.12751

Norton RA, Kethley JB, Johnston DE, O'Connor BM (1993) Phylogenetic perspectives on genetic systems and reproductive modes of mites. In: Wrensch D, Ebbert MA (eds) Evolution and diversity of sex ratio in insects and mites. Chapman \& Hall, New York, pp 8-99 
Oliveira DGPD, Kasburg CR, Alves LFA (2020) Efficacy of Beauveria bassiana against the poultry red mite, Dermanyssus gallinae (De Geer, 1778) (Mesostigmata: Dermanyssidae), under laboratory and hen house conditions. Syst Appl Acarol 25:895-905. https://doi.org/10.11158/saa.25.5.10

Osler GHR, Gauci CS, Abbott LK (2004) Limited evidence for short-term succession of microarthropods during early phases of surface litter decomposition. Pedobiologia 48:37-49. https://doi.org/10.1016/j. pedobi.2003.07.004

Pastwik E, Skorupski M, Piasta A, Jagodziński AM (2013) Mesostigmata mites of afforested post-industrial habitats on a lignite mine spoil heap in Bełchatów - a preliminary study. In: Neményi M, Varga L, Facskó F, Lőrincz I (eds) Science for sustainability. Proceedings of the International Scientific Conference for PhD Students. Győr, March 19-20, 2013. University of West Hungary Press, Sopron, pp 251-257

Piasta A, Skorupski M, Horodecki P, Jagodziński AM (2015) Zgrupowania roztoczy (Acari) pod drzewostanami sosnowymi na terenach leśnych i rekultywowanym zwałowisku zewnętrznym $\mathrm{w}$ Nadleśnictwie Bełchatów [Soil mite communities under Scots pine stands growing on forest sites and reclaimed lignite mine spoil heap in Bełchatów Forest District]. Studia i Materiały Centrum Edukacji Przyrodniczo-Leśnej w Rogowie 17:279-294

Pietrzykowski M (2010) Scots pine (Pinus sylvestris L.) ecosystem macronutrients budget on reclaimed mine sites—-stand trees supply and stability. Nat Sci 2:590-599

Pietrzykowski M, Daniels WL (2014) Estimation of carbon sequestration by pine (Pinus sylvestris L.) ecosystems developed on reforested post-mining sites in Poland on differing mine soil substrates. Ecol Eng 73:209-218. https://doi.org/10.1016/j.ecoleng.2014.09.058

Polis GA, Strong DR (1996) Food web complexity and community dynamics. Am Nat 147:813-846. https://doi.org/10.1086/285880

Rawlik M, Kasprowicz M, Jagodziński AM (2018a) Differentiation of herb layer vascular flora in reclaimed areas depends on the species composition of forest stands. For Ecol Manag 409:541-551. https://doi.org/10.1016/j.foreco.2017.11.055

Rawlik M, Kasprowicz M, Jagodziński AM et al (2018b) Canopy tree species determine herb layer biomass and species composition on a reclaimed mine spoil heap. Sci Total Environ 635:1205-1214. https://doi.org/10.1016/j.scitotenv.2018.04.133

Robakowski P, Bielinis E, Sendall K (2018) Light energy partitioning, photosynthetic efficiency and biomass allocation in invasive Prunus serotina and native Quercus petraea in relation to light environment, competition and allelopathy. J Plant Res 131:505-523. https://doi.org/10.1007/ s10265-018-1009-x

Roth MA, Wilson JM, Tignor KR, Gross AD (2020) Biology and management of Varroa destructor (Mesostigmata: Varroidae) in Apis mellifera (Hymenoptera: Apidae) colonies. J Integr Pest Manag. https://doi.org/10.1093/jipm/pmz036

Rudolf VHW, Rasmussen NL (2013) Population structure determines functional differences among species and ecosystem processes. Nat Commun 4:2318. https://doi.org/10.1038/ncomms3318

Sako A, Semde S, Wenmenga U (2018) Geochemical evaluation of soil, surface water and groundwater around the Tongon gold mining area, northern Cote d'Ivoire, West Africa. J Afr Earth Sci 145:297316. https://doi.org/10.1016/j.jafrearsci.2018.05.016

Salmane I, Spungíis V (2015) Factors influencing Mesostigmata mites (Acari, Parasitiformes) in the alkaline fen habitats. Proc Latv Acad Sci Sect B 69:50-56. https://doi.org/10.1515/prolas-2015-0006

Schmidt RA (2014) Leaf structures affect predatory mites (Acari: Phytoseiidae) and biological control: a review. Exp Appl Acarol 62:1-17. https://doi.org/10.1007/s10493-013-9730-6

Seniczak S, Seniczak A, Gwiazdowicz DJ, Coulson SJ (2014) Community structure of Oribatid and Gamasid mites (Acari) in Moss-Grass Tundra in Svalbard (Spitsbergen, Norway). Arct Antarct Alp Res 46:591-599. https://doi.org/10.1657/1938-4246-46.3.591

Seniczak S, Graczyk R, Seniczak A et al (2018) Microhabitat preferences of Oribatida and Mesostigmata (Acari) inhabiting lowland beech forest in Poland and the trophic interactions between these mites. Eur J Soil Biol 87:25-32. https://doi.org/10.1016/j.ejsobi.2018.04.004

Schulze ED (2000) Carbon and nitrogen cycling in European forest ecosystems. In: Ecological studies, vol 142. Springer, Berlin

Skorupski M (2010) Influence of selected tree species on forest ecosystem biodiversity for the example of Mesostigmata mites in a common-garden experiment. Uniwersytet Przyrodniczy w Poznaniu, Poznań, Poland

Skorupski M, Horodecki P, Jagodziński AM (2013) Roztocze z rzędu Mesostigmata (Arachnida, Acari) na terenach przemysłowych i poprzemysłowych w Polsce [Mite species of Mesostigmata order (Arachnida, Acari) in industrial and postindustrial areas of Poland]. Nauka Przyroda Technologie 7:\#11 
Skubała P (2002a) Development of oribatid mite communities (Acari, Oribatida) on a mine dump. In: Bernini F, Nannelli R, Nuzzaci G, de Lillo E (eds) Acarid phylogeny and evolution: adaptation in mites and ticks. Springer, Dordrecht

Skubała P (2002b) Rozwój fauny roztoczy na hałdach, czyli jak przyroda walczy z przemysłem [The development of mite fauna on dumps or how nature struggles with industry]. Kosmos 51:195-204

Thakur MP, Reich PB, Hobbie SE et al (2018) Reduced feeding activity of soil detritivores under warmer and drier conditions. Nat Clim Chang 8:75-78. https://doi.org/10.1038/s41558-017-0032-6

Tuka E, Solarz K (2017) Dynamika sezonowa i struktura populacji roztoczy Dermatophagoides w kurzu $\mathrm{z}$ miejsc do spania na terenie Sosnowca [Seasonal dynamics and population structure of Dermatophagoides in dust from sleeping places in the area of Sosnowiec city]. Alergoprofil 13:102109. https://doi.org/10.24292/01.ap.200517

Urbanowski CK, Horodecki P, Kamczyc J et al (2018) Succession of mite assemblages (Acari, Mesostigmata) during decomposition of tree leaves in forest stands growing on reclaimed post-mining spoil heap and adjacent forest habitats. Forests 9:718. https://doi.org/10.3390/f9110718

Urbanowski CK, Horodecki P, Kamczyc J et al (2021) Does litter decomposition affect mite communities (Acari, Mesostigmata)? A five-year litterbag experiment with 14 tree species in mixed forest stands growing on a post-industrial area. Geoderma 391:114963. https://doi.org/10.1016/j.geoderma.2021. 114963

Vacek Z, Prokůpková A, Vacek S et al (2021) Mixed vs. monospecific mountain forests in response to climate change: structural and growth perspectives of Norway spruce and European beech. For Ecol Manag 488:119019. https://doi.org/10.1016/j.foreco.2021.119019

Vitali V, Forrester DI, Bauhus J (2018) Know Your neighbours: drought response of Norway spruce, silver fir and Douglas fir in mixed forests depends on species identity and diversity of tree neighbourhoods. Ecosystems 21:1215-1229. https://doi.org/10.1007/s10021-017-0214-0

von Wendorff G (1952) Die Prunus serotina in Mitteleuropa. Eine waldbauliche Monographie. PhD Dissertation, Universitat Hamburg, Germany

Vreeken-Buijs MJ, Brussaard L (1996) Soil mesofauna dynamics, wheat residue decomposition and nitrogen mineralization in buried litterbags. Biol Fertil Soils 23:374-381. https://doi.org/10.1007/BF003 35910

Walter DE, Proctor HC (2013) Mites in soil and litter systems. In: Mites: ecology, evolution and behaviour. Springer, Dordrecht

Wissuwa J, Salamon J-A, Frank T (2012) Effects of habitat age and plant species on predatory mites (Acari, Mesostigmata) in grassy arable fallows in Eastern Austria. Soil Biol Biochem 50:96-107. https://doi. org/10.1016/j.soilbio.2012.02.025

Publisher's Note Springer Nature remains neutral with regard to jurisdictional claims in published maps and institutional affiliations. 